\title{
Pt-Based Intermetallic Nanocrystals in Cathode Catalysts for Proton Exchange Membrane Fuel Cells: From Precise Synthesis to Oxygen Reduction Reaction Strategy
}

\author{
Peng Gao ${ }^{1}$, Min Pu ${ }^{1} \mathbb{D}$, Qingjun Chen ${ }^{2,3, *}$ and Hong Zhu ${ }^{1, *}$ \\ 1 State Key Laboratory of Chemical Resource Engineering, Institute of Modern Catalysis, Department of \\ Organic Chemistry, Beijing Engineering Center for Hierarchical Catalysts, School of Science, Beijing \\ University of Chemical Technology, Beijing 100029, China; penggao1@buct.edu.cn (P.G.); \\ pumin@mail.buct.edu.cn (M.P.) \\ 2 Ganjiang Innovation Academy, Chinese Academy of Sciences, Ganzhou 341000, China \\ 3 Zhongke Langfang Institute of Process Engineering, Fenghua Road No 1, Langfang Economic \& Technical \\ Development Zone, Langfang 065001, China \\ * Correspondence: qjchen@ipe.ac.cn (Q.C.); hzhu@mail.buct.edu.cn (H.Z.)
}

\section{check for} updates

Citation: Gao, P.; Pu, M.; Chen, Q.; Zhu, H. Pt-Based Intermetallic Nanocrystals in Cathode Catalysts for Proton Exchange Membrane Fuel Cells: From Precise Synthesis to Oxygen Reduction Reaction Strategy. Catalysts 2021, 11, 1050

https://doi.org/

10.3390/catal11091050

Academic Editor: Mohamed

Ali Ghanem

Received: 20 July 2021

Accepted: 26 August 2021

Published: 30 August 2021

Publisher's Note: MDPI stays neutral with regard to jurisdictional claims in published maps and institutional affiliations.

Copyright: (c) 2021 by the authors. Licensee MDPI, Basel, Switzerland. This article is an open access article distributed under the terms and conditions of the Creative Commons Attribution (CC BY) license (https:// creativecommons.org/licenses/by/ $4.0 /)$.

\begin{abstract}
Although oxygen reduction reaction (ORR) catalysts have been extensively investigated and developed, there is a lack of clarity on catalysts that can balance high performance and low cost. Pt-based intermetallic nanocrystals are of special interest in the commercialization of proton exchange membrane fuel cells (PEMFCs) due to their excellent ORR activity and stability. This review summarizes the wide range of applications of Pt-based intermetallic nanocrystals in cathode catalysts for PEMFCs and their unique advantages in the field of ORR. Firstly, we introduce the fundamental understanding of Pt-based intermetallic nanocrystals, and highlight the difficulties and countermeasures in their synthesis. Then, the progress of theoretical and experimental studies related to the ORR activity and stability of Pt-based intermetallic nanocrystals in recent years are reviewed, especially the integrated strategies for enhancing the stability of ORR. Finally, the challenges faced by Pt-based intermetallic nanocrystals are summarized and future research directions are proposed. In addition, numerous design ideas of Pt-based intermetallic nanocrystals as ORR catalysts are summarized, aiming to promote further development of commercialization of PEMFC catalysts while fully understanding Pt-based intermetallic nanocrystals.
\end{abstract}

Keywords: proton exchange membrane fuel cells; oxygen reduction reaction; intermetallic; Pt alloy

\section{Introduction}

Energy is the economic lifeline on which humankind depends for its survival and development. Every energy revolution will have a profound impact on human society. In the 21st century, rapid population growth and social-economic development increased the supply burden of carbon-based fuels in human society. The accompanying global warming and environmental pollution have prompted mankind's eagerness to change the existing energy structure. Hydrogen is widely recognized as a good candidate for new energy sources, because it is an energy-efficient, clean, and fuel-flexible secondary energy carrier. Through fuel cells, hydrogen can be the perfect bridge between many renewable and fossil energy sources. Especially in the field of transportation applications, proton exchange membrane fuel cells (PEMFCs) have received attention due to their high energy conversion efficiency, high energy density, environmental friendliness, and low operating temperature [1]. It is worth noting that the PEMFCs already have economic advantages over lithium-ion batteries as the main power source for long-range heavy-duty vehicles and buses. Many vehicle manufacturers, including Toyota, Hyundai and General Motors, have already rolled out their corresponding fuel cell vehicle products [2]. However, the present 
progress is far from meeting the needs of the wide application of PEMFCs in light-duty vehicles $[3,4]$.

One of the bottlenecks for PEMFCs stems mainly from the expensive platinum group catalysts at both ends of the membrane electrode assembly (MEA). Especially on the cathode side, the exchange current density for oxygen reduction reaction (ORR) is 5-6 orders of magnitude slower than that of the anode side where hydrogen oxidation reaction (HOR) occurs [5]. Over the past two decades, the catalysts have been heavily explored to achieve high activity, high stability and low cost [6]. These catalysts include Pt/C, Pt-alloy, core-shell, shape-controlled nanocrystal, nanoframe/nanocage, and non-precious metal catalyst [7]. In particular, Pt-alloy catalysts are the new generation of commercial benchmark catalysts due to their simple synthesis process, as well as higher activity and stability than $\mathrm{Pt} / \mathrm{C}$ catalysts [8]. However, as the alloying element is always late first-row transition metal elements ( $\mathrm{Fe}, \mathrm{Co}, \mathrm{Ni}$, etc.), it cannot avoid dissolving these elements in the electrolyte under severe acidic conditions of PEMFCs, thus resulting in decay in both activity and stability $[9,10]$. Thankfully, the issue of poor stability of these catalysts can be mitigated by the formation of corresponding intermetallic compounds, which are usually obtained after long-term high-temperature treatment $\left(>500{ }^{\circ} \mathrm{C}\right)$ [11]. The resulting equilibrated stable structure gives the intermetallic compounds robust stability [12]. Considering the excellent activity and stability of intermetallic nanocrystals, the use of intermetallic nanocrystals in fuel cells will reduce the Pt loading and greatly reduce the cost. Moreover, the atomic ordering within the nanoparticles (NPs) makes the catalysts expose more active sites than the disordered counterpart, which not only increases the activity of the catalyst by strong strain and ligand effects, but also makes it easy to study the structure-performance relationship between extended and nanoscale Pt surfaces, so as to explore more latent factors or descriptors affecting both the activity and stability [13,14].

In recent years, there has been explosive growth in the study of Pt-based intermetallic nanocrystals for ORR, from theoretical calculation to experimental verification, from precise synthesis to excellent electrocatalytic properties (Figure 1) [12,15-18]. Most of the reviews focus on the study of structure-activity relationship of intermetallic $[12,16,19]$. In this review, we emphasize the important role of Pt-based intermetallic nanocrystals as electrocatalysts in enhancing the stability of acidic ORR based on the principle of practicality. In order to better understand the application of intermetallic compounds in ORR, we firstly introduce the definition, superiority and classification of Pt-based intermetallic nanocrystals. Then, the experimental conditions, difficulties and corresponding synthetic methodologies of intermetallic nanocrystals are outlined. Next, the theoretical and experimental progress that correlates ORR activity and stability with intermetallic nanocrystals is reviewed, followed by a discussion of synergistic strategies to enhance ORR performance, especially stability. Finally, we summarize challenges faced by Pt-based intermetallic nanocrystals for ORR and their future research directions. The purpose of this review is to give a systematic introduction to the researchers who are new to this field, and provides constructive and practical suggestions to peers in this field. 


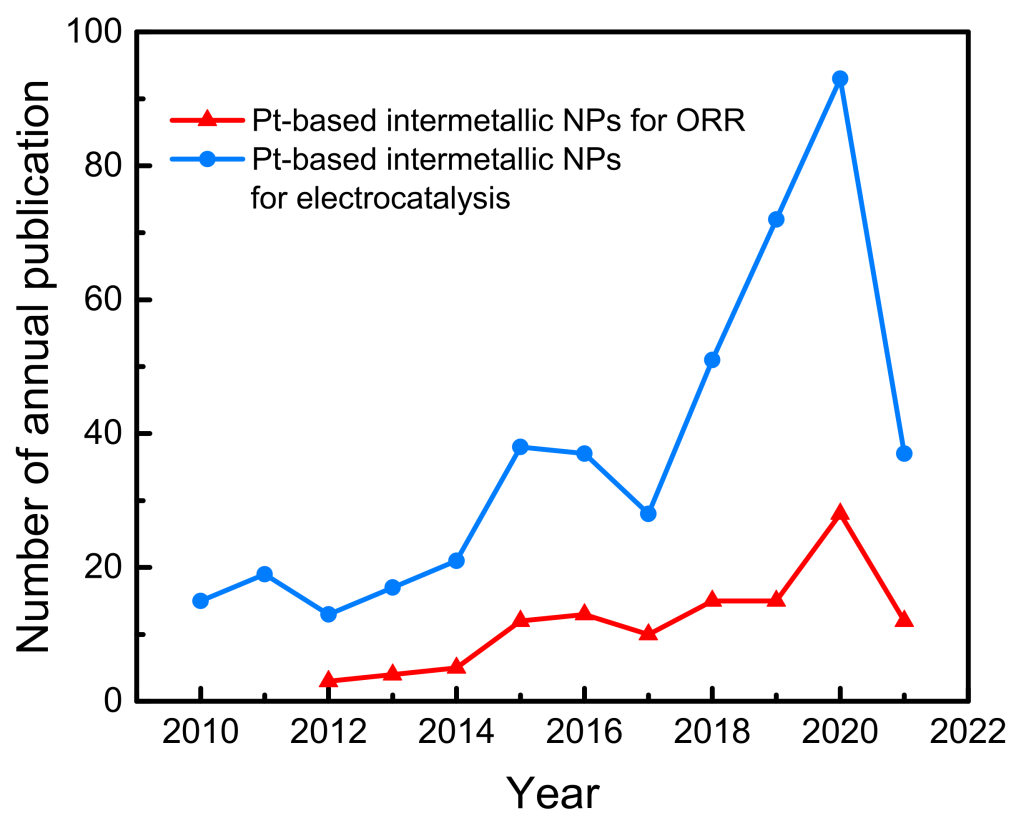

Figure 1. Number of articles on Pt-based intermetallic NPs in the field of ORR or electrocatalysis in the last decade according to Clarivate Analytics.

\section{Fundamental Understanding of Pt-Based Intermetallic Nanocrystals}

\subsection{Definition of Intermetallic Nanocrystals}

Intermetallic nanocrystals are one kind of bi- or multi-metallic NPs in which the metal atoms are ordered in a crystallographic direction [11]. Under a certain reaction temperature and stoichiometry, the intermetallic nanocrystals are formed. This process is called the ordering transformation process, which is usually exothermic. Owing to the strong chemical bonding, the formed intermetallic has both ionic and covalent bonding properties [20]. Unlike solid solutions such as substitutional solid solution and interstitial solid solution, the intermetallic shows a completely different crystal structure and a more unique electronic structure than the parent metal because of their strong $\mathrm{d}$-orbital interaction and thus highly ordered atomic arrangements, even though they have the same stoichiometric number [19]. For example, the $\mathrm{L} 1_{0}$ phase $\mathrm{PtFe}$ face-centered tetragonal (fct) structure (space group: $\mathrm{P} 4 / \mathrm{mmm}$ ) compresses the $\mathrm{Z}$ axis of the $\mathrm{A} 1$ phase PtFe face-centered cubic (fcc) structure (space group: $\mathrm{Fm}-3 \mathrm{~m}$ ) due to the alternate arrangement of atomic layers of $\mathrm{Pt}$ and Fe elements [18]. This different crystal structure combined with particular bonding properties endows intermetallic nanocrystals with superior catalytic performance over the corresponding NPs. As mentioned in the introduction, the atomic ordering increases the active site density of the catalyst, while the thermodynamically stable structure allows the intermetallic compounds to be remarkably resistant to harsh catalytic environments. More importantly, the ordered structure of intermetallic compounds in nanoscale is friendly to theoretical calculation. The well-defined stoichiometry and controlled crystal structure enable a good agreement between theoretical and experimental results. Therefore, a reliable structure-performance relationship could be concluded, which makes it possible for the theoretical calculation to guide the synthesis of actual experiments in nanoscale [21].

\subsection{Classification of Pt-Based Intermetallic Nanocrystals}

Most of the disordered Pt-based solid solutions denoted as A1 are fcc structure, in which all atoms are randomly distributed on eight vertices and six faces in unit cell [22]. When A1 solid solution is transformed into an ordered one, a wide range of superstructures are generated depending on their alloying composition (Figure 2). The following superstructures are common in recent literature. $1 . \mathrm{L}_{0}$, fct structure, $\mathrm{AB}$ type, is similar to the A1 structure, with the difference that only four of the six face-centered atoms, except 
for the two bottom-centered atoms, are replaced by alloying atoms, showing tetragonal distortion. 2. $\mathrm{L}_{1}, \mathrm{AB}$ type, Pt atoms alternate with alloying atoms on the (111) facets, showing rhombohedral distortion. 3 . $\mathrm{L}_{2}$, fcc structure, $\mathrm{AB}_{3}$ type. The $\mathrm{B}$ atoms are located at six face-centered positions, while the A atoms occupy the eight corner positions. The element $\mathrm{B}$ can be either Pt or an alloying element. 4. $\mathrm{L1}_{3}, \mathrm{AB}_{3}$ type. This structure can be interpreted as a transformation of the $\mathrm{L}_{1}$ structure, in which four face-centered positions that $\mathrm{z}$-coordinate are $1 / 2$ in $\mathrm{L}_{1}$ unit cell are occupied by $\mathrm{B}$ atoms [23]. In addition to the four structures mentioned above, there is another structure, named $\mathrm{Ga}_{3} \mathrm{Pt}_{5}$, which can be simplified to the fcc structure if Ga atoms are replaced by $\mathrm{Pt}$ [11]. The diversity of superstructures will inevitably lead to different local geometric and electronic structures of NPs, thus giving NPs new performance potential, which makes the "blue ocean" of intermetallic compounds look even more fascinating.

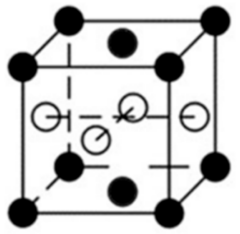

a

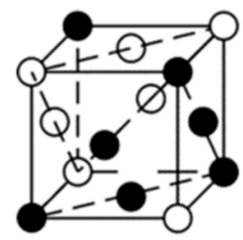

$b$

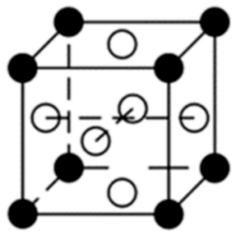

C

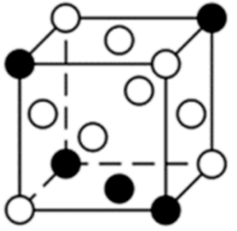

$d$

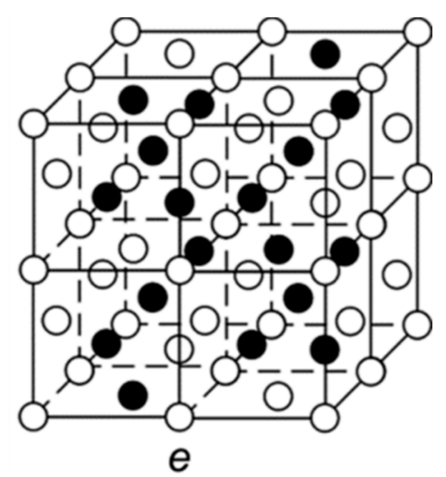

Figure 2. Unit cell of the sample superstructures: $\mathrm{L}_{0}(\mathbf{a}), \mathrm{L}_{1}(\mathbf{b}), \mathrm{L}_{2}$ (c), $\mathrm{L1}_{3}$ (d), and $\mathrm{Ga}_{3} \mathrm{Pt}_{5}$ (e). Reproduced with permission [23]. Copyright 2013 Springer Nature.

\subsection{Synthesis of Pt-Based Intermetallic Nanocrystals}

Intermetallic compounds are an important class of alloy materials. Their bulk materials have been widely used in the fields of superconductivity, shape memory and hydrogen storage [24-26].

In recent years, the application of Pt-based intermetallic nanocrystals has attracted extensive attention, especially in the field of catalysis [27-29]. Since the successful synthesis of monodisperse Pt-Fe intermetallic nanocrystals by Sun's group in 2000, more and more attention has been paid to the synthesis of ordered nanocrystals $[30,31]$. There are quite a few recent studies for Pt-based intermetallic NPs for fuel cells [32-36].

For Pt-based intermetallic NPs, the synthesis process can be summarized as the generation of disordered NPs and the transformation of disordered structures to ordered structures [37-39]. The synthesis of disordered NPs can be conducted by gas-phase or liquid-phase methods. The gas-phase reduction includes impregnation reduction and chemical vapor deposition (CVD), while the liquid-phase methods are mainly polyol methods, seed-mediated growth methods, colloidal synthesis, and hydrothermal synthesis, etc. [40-46]. The aim of the above methods is to obtain NP precursors with homogeneous morphology and small size [47]. However, currently, the disordered-to-ordered transition process of alloy NPs can only be performed at high temperatures. For example, ordered $\mathrm{Pt}_{3} \mathrm{Fe}$ NPs can be formed by heating at $650{ }^{\circ} \mathrm{C}$ for $2 \mathrm{~h}$ under a nitrogen atmosphere. It is difficult to obtain the same particle size distribution as that of disordered counterpart, thus limiting the application of Pt-based intermetallic nanocrystals in the field of catalysis. The synthesis of Pt-based intermetallic compounds mainly has the following difficulties.

I. Less driving force for ordering reconstruction than that of bulk counterpart 
From a thermodynamic point of view, the ordering process of NPs differs from that of the bulk materials by the following expression,

$$
\Delta G_{d \rightarrow o}=\Delta H_{d \rightarrow 0}-T \Delta S_{d \rightarrow o}+\Delta \gamma_{d \rightarrow 0} A
$$

where $\Delta G_{d \rightarrow o}$ is the change in Gibbs' free energy of the ordering process of NPs, whereas $\Delta H_{d \rightarrow 0}, \Delta S_{d \rightarrow 0}$ and $\Delta \gamma_{d \rightarrow 0}$ are the corresponding changes in enthalpy, entropy and surface free energy, respectively. A is the surface area of NPs, and T is the temperature. For the generation of stable intermetallic compounds, $\Delta H_{d \rightarrow 0}$ and $\Delta S_{d \rightarrow 0}$ are negative and the value of $\Delta \gamma_{d \rightarrow 0}$ is positive. Therefore, the huge specific surface area makes $\Delta \gamma_{d \rightarrow 0} A$ nonnegligible for NPs, leading to a larger $\Delta G_{d \rightarrow o}$ than that of bulk counterpart [15]. As a result, it is impossible for some materials that would otherwise yield intermetallic compounds in bulk materials to achieve some degree of ordering at the nanoscale when the particle size is less than a certain value $[48,49]$.

II. High kinetic barriers

Even though the small NPs can boost the surface diffusion, thus reducing the diffusion energy barrier to some extent, the remaining atomic diffusion barrier still needs to be overcome at high temperatures [50]. Despite the fact that high temperature can increase the diffusion rate, the overall driving force will decrease, and the target product is impossible to be synthesized, considering the ordering process is a negative entropy process in Equation (1) [51]. In other words, the ordering process requires high temperature, whereas the intermetallic compounds themselves are thermodynamically stable at low temperatures. This contradiction puts a limit on conditions (particle size, morphology and composition, etc.) that Pt-based NPs need to undergo, and the temperature that the ordered compounds can be generated. Or, on the other hand, whether the dilemmas created above can be changed by other means, such as further lowering the diffusion barrier.

\section{Severe agglomeration of NPs caused by high temperature}

Pt-based NPs are usually used in electrocatalysis, where their high catalytic activity area is one of the must-have parameters. Although high temperature can accelerate the ordering, it also makes NPs more prone to aggregation and sintering at the same time, which severely affects the catalytic performance of NPs [52]. Therefore, an appropriate confinement strategy is necessary and will be presented in detail in the subsequent sections.

\section{Precise control of element composition}

In addition to temperature control, precise atomic composition is one of the necessary conditions for the synthesis of intermetallic compounds. The uniformity of particle size and element distribution of NPs is the basis for the synthesis of well-defined intermetallic compounds. This calls for high criteria for the synthesis of NP precursors. Moreover, the electronegativity of the elements also has an implication on the difficulty of synthesis. The greater difference in electronegativity of the alloying elements, the more precise ratio of intermetallic compounds is required [15]. Therefore, different synthesis methods have a profound impact on the final product [29].

\subsection{Factors Affecting the Formation of Pt-Based Intermetallic Nanocrystals}

Despite the difficulties discussed above, researchers can obtain the target intermetallic nanocrystals by fine-tuning the various parameters and by well applying different circumventions in the synthesis of ordered NPs. These variables include alloying element, particle size, crystal facets, temperature, etc. From the perspective of facets, Chi et al. explored the evolution of different facets of ordered nanocrystals at different temperatures in the Pt-Co system [53]. From the particle size point of view, Liu et al. reported that the Pt-Fe NPs do not form ordered structures with particle sizes smaller than $2 \mathrm{~nm}$ [48]. In terms of temperature, Sun et al. reported that the ordering temperature of Pt-Fe NPs with a particle size of $6 \mathrm{~nm}$ is $530^{\circ} \mathrm{C}$ under high vacuum conditions [54]. 
There are also interconstraint relationships among those variables. For example, $\mathrm{Pt}$ $\mathrm{Fe}$ and Pt-Co NPs are considered easy to form intermetallic nanocrystals, while Pt-Ni is difficult. This is due to both thermodynamic and kinetic factors. The formation enthalpy of $\mathrm{Pt}-\mathrm{Ni}$ intermetallic is smaller than that of $\mathrm{Pt}-\mathrm{Fe}$ and $\mathrm{Pt}-\mathrm{Co}$, which makes the size of target Pt-Ni NPs not too small, usually at least $8 \mathrm{~nm}$. The ordering temperature should not be too high, generally less than $600{ }^{\circ} \mathrm{C}$ ( $\mathrm{PtNi}$ bulk phase transition temperature) according to Equation (1) [55-58]. Meanwhile, on the basis of Johnson-Mehl-Avrami (JMA) theory and Einstein model, we can conclude that the integrated diffusion rate of $\mathrm{Ni}$ in the lattice is also slower than that of $\mathrm{Co}$ and Fe [15]. Therefore, a longer duration of high temperature is required (often more than $6 \mathrm{~h}$ ) $[55,56]$. This is the main reason why few Pt-Ni intermetallic nanocrystals have been reported so far [59].

The examination of formation mechanisms of intermetallic is the cornerstone of the controlled synthesis of intermetallic compounds. It is meaningful to study the dynamic process of ordering by in-situ methods with different annealing conditions on the degree of ordering, as well as the phase transformation and morphological changes during the real-time annealing process [60]. Strasser et al. investigated the relationship between heating parameters and alloying microstructures in the carbon-supported $\mathrm{Pt}-\mathrm{Cu}$ system using in-situ high-temperature X-ray Diffraction (HT-XRD) [61]. Some of the important conclusions are as follows. 1 . The upper limit of the heating temperature determines the extent to which $\mathrm{Cu}$ elements can be incorporated into the alloy system. 2. When the heating time exceeds $1.5 \mathrm{~h}$, the degree of alloy mixing does not change significantly, but only makes the particles grow up gradually. 3 . The ordered structure is obtained only in the cooling process. Similar results are confirmed for the Pt-Ni system. Weidenthaler et al. analyzed the formation mechanism of the ordered-disordered transformation of $\mathrm{Pt}-\mathrm{Ni}$ alloys during stepwise heat treatment using in situ high-resolution X-ray powder diffraction (HR-XRPD) and X-ray paired distribution (PDF) analyses [62]. The comparative characterization of in-situ and ex-situ methods demonstrates that in the Pt-Ni-ordered reconfiguration process, a slow stepwise cooling process leads to the generation of partially ordered structures (Figure 3a). The authors also emphasized that for the Pt-Ni system, the process of ordering transition takes a long time ( $>20 \mathrm{~h})$. Moreover, it is noteworthy that the size of the Pt-Ni NPs synthesized in their work is only 5-6 nm, while the hollow graphitic spheres (HGSs) are very stable, which is beneficial for fuel cells and other electrocatalytic applications $[41,63]$. Considering the important role of the Pt-Co system in the field of ORR, Abruña et al. quantified the effect of different heating conditions on the ordering degree of $\mathrm{Pt}_{3} \mathrm{Co} \mathrm{NPs}$ using in-situ XRD technique (Figure 3b,c). They directly observed the changes in $\mathrm{Pt}_{3} \mathrm{Co} \mathrm{NP}$ morphology by in situ scanning transmission electron microscopy (STEM) at the atomic scale [64]. Finally, it was concluded that the $\mathrm{Pt}_{3} \mathrm{Co}$ NPs with a $30 \%$ order degree obtained under the heating condition of $2 \mathrm{~h}$ at $750{ }^{\circ} \mathrm{C}$ show the best MEA performance. By means of in-situ characterization, we can not only visualize and gain insights into the ordering process, but also make unexpected discoveries. From the identical location STEM (ILSTEM) images of structurally ordered $\mathrm{PtCu}_{3} / \mathrm{C}$, Gaberšček et al. indirectly found that $\mathrm{Cu}$ can migrate and aggregate on the carbon support in the form of single atoms, which is the main reason for the particle growth and responsible for the generation of intermetallic structure below $500{ }^{\circ} \mathrm{C}$. The main reason for the NP size growth at higher temperature $\left(>500{ }^{\circ} \mathrm{C}\right)$ is attributed to the coalescence (Figure 3d) [65]. This finding, together with the double-passivation effect previously discovered by the same team will have profound guidance for the particle size control of intermetallic compounds during high-temperature annealing [66]. 
a

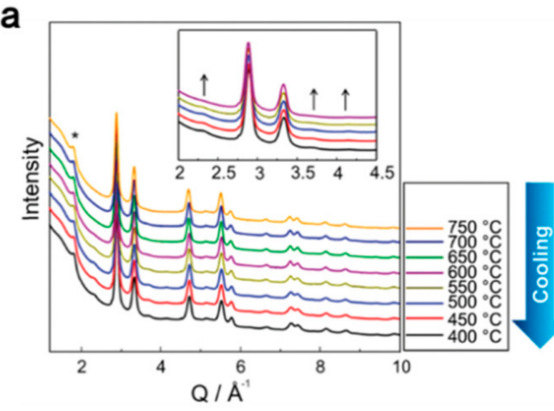

d

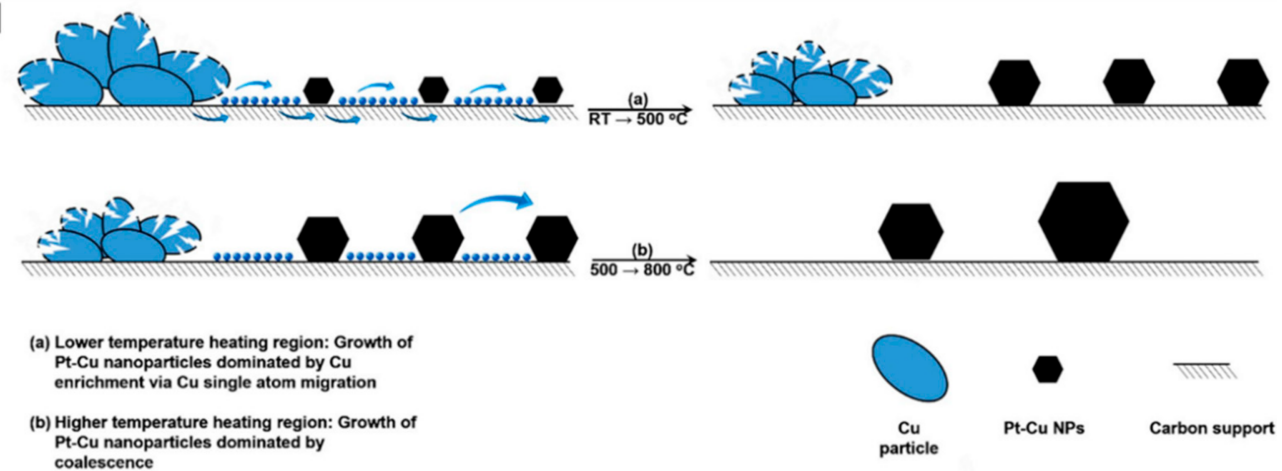

b

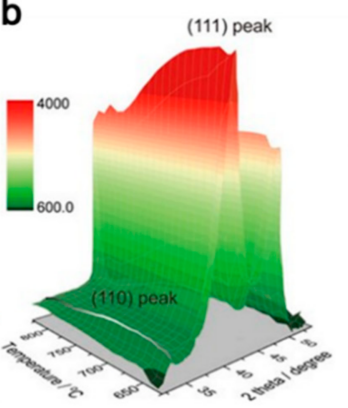

C

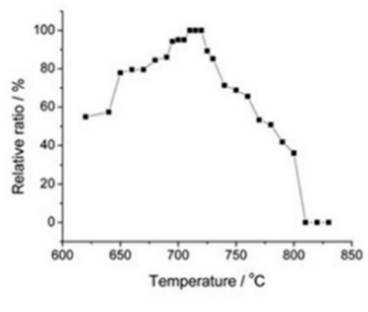

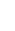


corrected STEM. This is due to the surface segregation of $\mathrm{Pt}$ in $\mathrm{Pt}_{3} \mathrm{Fe}_{2}$ at high temperatures. Because of the increased Fe content, Pt atoms in $\mathrm{Pt}_{3} \mathrm{Fe}_{2}$ NPs are even more susceptible to surface segregation than $\mathrm{Pt}$ atoms in $\mathrm{Pt}_{3} \mathrm{Fe} \mathrm{NPs}$, which gives the catalyst excellent ORR stability [79].

\subsection{Structure Characterization of Pt-Based Intermetallic Nanocrystals}

The structure identification of Pt-based intermetallic nanocrystals is mainly through the XRD patterns. The long-range ordered superstructure in intermetallic compounds can be detected by X-ray diffraction, which shows a certain peak intensity at the corresponding low index crystal plane and can be identified by comparison with a standard card [80]. This is by far the most convenient and fast way to identify ordered structures. The ordering degree can be quantitatively estimated by the intensity ratio of the ordered characteristic peak to the conventional alloy peak [48,81]. In STEM images, the ordered arrangement of atoms can be directly distinguished by regular differences in the $Z$ contrast [82]. The crystal plane information of the ordered structure can be obtained by selected area electron diffraction (SAED) pattern and fast Fourier transform (FFT) pattern [83]. In the extended $X$-ray absorption fine structure (EXAFS) analysis, the intermetallic nanocrystals have more $\mathrm{Pt}-\mathrm{M}$ bonds and less $\mathrm{Pt}-\mathrm{Pt}, \mathrm{M}-\mathrm{M}$ bonds than disordered alloys, due to a higher alloying degree [14]. The Rietveld analysis and PDF analysis are also used to determine whether an ordered structure has been generated by comparing the fit residual [62]. New properties due to the ordered structure can also be used to discern whether the superstructure is generated or not. For example, the ordered Pt-Fe NPs are strongly ferromagnetic. Therefore, the coercivity of the samples can be used to determine whether the ordered structure is formed [84].

\section{ORR Catalytic Properties of Pt-Based Intermetallic Nanocrystals}

\subsection{Activity of Pt-Based Intermetallic Nanocrystals}

The factors that affect the ORR activity of Pt-based intermetallic nanocrystals can be briefly interpreted by the following two equations.

$$
\begin{gathered}
\text { Mass activity }(\mathrm{MA})=\text { Specific activity }(\mathrm{SA}) \times \text { Electrochemical surface area }(\mathrm{ECSA}) \\
\qquad \mathrm{SA} \propto i=n F K c_{\mathrm{O}_{2}}\left(1-\Theta_{a d}\right)^{x} e^{-\beta F E / R T} e^{-\gamma \Delta G_{a d} / R T}
\end{gathered}
$$

MA is a comprehensive factor to evaluate whether a catalyst has practical value. This parameter is closely related to the amount of Pt utilized. By increasing the mass activity, the cost of the catalysts in fuel cells can be effectively reduced. According to Equation (2), for a fixed SA, increasing the ECSA of the catalyst, i.e., and decreasing the particle size of the NPs, can effectively increase the MA. The SA reflects the intrinsic activity of a catalyst. Equation (3) shows the factors that affect SA based on the associative ORR pathway, where E, T, $\Theta_{a d}$, and $\Delta G_{a d}$ are the electrode potential, temperature, total surface coverage of spectator species, and Gibbs free energy of adsorption of reactive intermediates, respectively [8]. According to Equation (3), the SA in the ORR process is closely related to the adsorption of oxygen-containing intermediates $\left(\mathrm{OH}_{\mathrm{ad}}\right)$ on the catalyst surface. The adsorption behavior of $\mathrm{OH}_{\mathrm{ad}}$ on the Pt (111) surfaces has been extensively studied by d-band theory [85-87]. The position of $\mathrm{d}$-band center $\left(\varepsilon_{d}\right)$, which is highly relevant to the adsorption energy of $\mathrm{OH}_{\mathrm{ad}}$, can be regulated by modulating the atomic spacing of surface Pt atoms (strain effect), or by changing the type and amount of ligand atoms of Pt (ligand effect) [12,88-92]. In the same way, the ORR catalysis process follows the Sabatier principle that there is an optimal $\mathrm{Pt}-\mathrm{O}$ binding energy $\left(\mathrm{E}_{\mathrm{O}}\right)$ located at the top of the volcano curve, which maximizes the ORR activity [93]. Although the ORR process is a complex multi-step reaction, the binding energy of the optimal ORR catalyst is determined to be $0.2 \mathrm{eV}$ weaker than that of $\mathrm{Pt}$ for oxygen $\left(\Delta \mathrm{E}_{\mathrm{O}}=0.2 \mathrm{eV}\right)$ or $0.1 \mathrm{eV}$ weaker for $\mathrm{OH}_{\mathrm{ad}}\left(\Delta \mathrm{E}_{\mathrm{OH}}=0.1 \mathrm{eV}\right)[92,94]$. Alloying Pt with $3 \mathrm{~d}$ transition metals, i.e., $\mathrm{Fe}, \mathrm{Co}, \mathrm{Ni}$, etc., is an effective way to adjust the electronic state of $\mathrm{Pt}$ atoms on the catalyst surface by strain effect or ligand effect $[95,96]$. This state can 
be further strengthened by the formation of corresponding intermetallic compounds from both density functional theory (DFT) calculation and in-situ XAFS characterization perspectives $[97,98]$. Many experimental results can also demonstrate that the ORR performance of Pt-based alloys with intermetallic structures is superior to that of the corresponding disordered alloys, that is, the intermetallic structure elevates the SA of Pt-based catalysts towards ORR [39,75,98-100]. More interestingly, it has been shown that the additional shear strain of $\mathrm{L} 1_{0}$-intermetallic NPs can further optimize the SA in the ORR process [101]. Therefore, intermetallic nanocrystals have higher MA than disordered alloys with the same particle size. At present, the cost reduction method of Pt-based catalyst is mainly derived from this.

\subsection{Stability of Pt-Based Intermetallic Nanocrystals}

The composition and structure of Pt-based alloys usually evolve dynamically during electrocatalytic processes. It is not enough to focus only on the initial activity of the catalyst. The dynamic evolution of the NPs in the catalytic process is even more important. That is, whether the high activity of a catalyst can be maintained after accelerated durability test (ADT) is the key to the commercialization of the catalyst. Although the current research on the structure-activity relationship of Pt-based catalysts has made great progress, the research advance on the relationship between structure and stability is still slow [102-106]. According to the present study, three main mechanisms of ORR deactivation of NPs are known, which are dissolution of NPs, growth of NPs by Ostwald ripening or NP agglomeration, and detachment of NPs from the carbon support surface, respectively [107-110]. As carbon support are recognized the support of Pt-based intermetallic catalyst, their degradation is inevitable. The probability of agglomeration of NPs is low in porous carbon support or in a confinement strategy, which is commonly adopted in the synthesis processes of intermetallic compounds. Ostwald ripening is also based on particle dissolution. Therefore, $\mathrm{Pt}$ dissolution is the main deactivation mechanism in Pt-based intermetallic nanocrystals. The dissolution mechanism of $\mathrm{Pt}$ is mainly divided into electrochemical dissolution and chemical dissolution which are described by the following equations [111].

$$
\begin{gathered}
\mathrm{Pt}_{\mathrm{n}} \rightarrow \mathrm{Pt}_{\mathrm{n}-1}+\mathrm{Pt}^{2+}(\mathrm{aq})+2 e^{-} \\
\mathrm{Pt}_{\mathrm{n}}+\mathrm{H}_{2} \mathrm{O}(\mathrm{aq}) \rightarrow \mathrm{O}-\mathrm{Pt}_{\mathrm{n}}+2 \mathrm{H}^{+}(\mathrm{aq})+2 e^{-} \\
\mathrm{O}-\mathrm{Pt}_{\mathrm{n}}+2 \mathrm{H}^{+}(\mathrm{aq}) \rightarrow \mathrm{Pt}_{\mathrm{n}-1}+\mathrm{Pt}^{2+}(\mathrm{aq})+\mathrm{H}_{2} \mathrm{O}(\mathrm{aq})
\end{gathered}
$$

From the above equation, it is clear that the stability of Pt NPs can be enhanced to some extent by enhancing the redox potential of Pt or by decreasing the percentage of $\mathrm{Pt}$ atoms in the oxidation state on the catalyst surface. Alloying Pt with $3 \mathrm{~d}$ transition metals elements can further reduce the oxidation state of Pt on the NPs surface, while at the same time lowering the d-band center and weakening the adsorption with $\mathrm{OH}_{\mathrm{ad}}$, thus reducing the dynamic disturbance caused by strong adsorption of $\mathrm{OH}_{\mathrm{ad}}$ on the NPs surface. It has been shown that $\mathrm{Pt}$ dissolution is related to the d-band center, and $\mathrm{Pt}$ dissolution decreases as the d-band center lowers [111]. Therefore, increasing the ORR activity of Pt-based NPs can simultaneously increase its catalytic stability, which can be said to kill two birds with one stone. Li et al. reported that the ORR stability of Pt single crystals is independent of the initial particle size and shape of NPs [112]. This suggested that the factors affecting the ORR stability of Pt-based catalysts are the composition of corresponding NPs. Cao et al. combined Kinetic Monte Carlo (KMC) simulations with experimental results to demonstrate that the ORR stability of the catalyst is not only related to the NP composition but also to the surface Pt content. The increased surface Pt content reduces the generation of surface vacancies and inhibits the surface migration and dissolution of alloying elements [113]. It has been demonstrated that the degree of retention of catalyst activity after ADT is directly proportional to the percentage of alloying metal elements retained inside the NPs $[114,115]$. Therefore, tuning the surface constituents of Pt-based catalysts can lead to both high activity and stability of the catalysts. 
From the above discussion, it is clear that a high-performance Pt-based catalyst should undergo a refinement of the local surface atomic structure. The ORR stability of the catalyst is synergistically enhanced by the electronic effect (d-band center) and geometric effect (intact Pt shell). The Pt-based intermetallic compounds are such nanocrystal with excellent catalytic stability. Its stability advantages can be summarized as follows.

I. Pt-based intermetallic nanocrystals are usually obtained by long-term high-temperature annealing, whose structures have stronger thermal stability than those nanostructures formed in the low-temperature liquid phase [116].

II. Pt-based intermetallic nanocrystals have a higher amount of Pt-M bond than disordered alloys in the full time period of the ORR process [14].

III. The uniform distribution of the subsurface elements in the Pt-based intermetallic nanocrystals gives a stronger strain effect on the Pt shell than in disordered alloys [101].

IV. The dissolution potential of alloying metal elements of Pt-based intermetallic nanocrystals is higher than that of disordered counterparts [117].

V. A stable, defect-free and homogeneous Pt shell structure can be formed after dealloying treatment for Pt-based intermetallic nanocrystals [118].

The unique local atomic arrangement of Pt-based intermetallic nanocrystals with strong $\mathrm{d}-\mathrm{d}$ interactions among alloy atoms gives them promising property for catalysis, and their structures after dealloying treatment can be visualized in Figure 4 [14]. The Pt shell formed on the surface is thin and homogeneous due to the uniform elemental distribution of the intermetallic compound. In contrast, the inhomogeneous distribution of elements in the disordered structure leads to the uneven Pt shell layer on the surface of NPs. Pt atoms with lower coordination numbers are less stable [119]. Therefore, the rough structure is susceptible to erosion in the catalytic process, which eventually leads to the formation of thicker Pt shells or the complete dissolution of the NPs, thus further reducing the ORR activity.
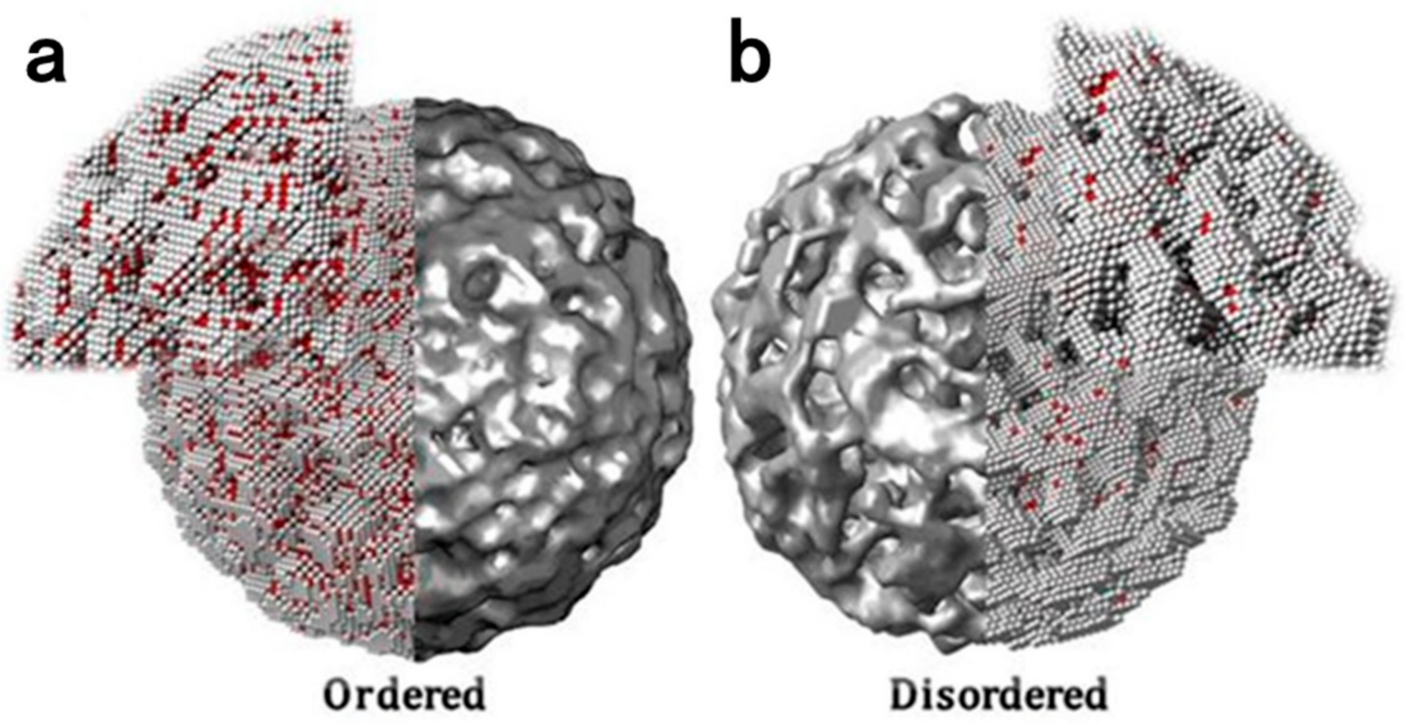

Figure 4. Disordered and ordered particles after acidic treatment: simulated ordered particle at the tipping point of pore creation (a) and disordered particle with developed porosity (b), taken at the same time [14]. Copyright 2016 American Chemical Society.

\subsection{ORR Strategy Based on Pt-Based Intermetallic Nanocrystals}

In view of excellent ORR activity and stability of Pt-based intermetallic nanocrystals, advanced ideas are developed to further enhance the performance of the catalysts, including further reduction in NP size, optimization of the local atomic arrangement and the alloy composition of NPs, and the enhancement of metal-support interaction. The detailed 
strategies include NP confinement, core-shell structures, the introduction of N elements, ternary intermetallic, and the introduction of non-Fe, $\mathrm{Co}, \mathrm{Ni}$, etc., alloying metal elements. Different strategies may be used for the same catalyst. A brief discussion of the latest research progress is given below.

\subsubsection{Size Control}

Even though both theoretical calculations and experiments demonstrate that increasing the particle size increases the SA of the particles, the particle size of the catalyst with the highest MA is between 2-3 nm [120-122]. The small particle size maximizes Pt utilization and boosts mass transfer through high dispersion in the catalytic process. This proves the practical value of catalysts with small particle sizes. Recently, it has been shown that the surface of Pt atoms is more oxygenophilic when the NP size is in the range of $2-4 \mathrm{~nm}$. The resulting stable layer of $\mathrm{PtO}_{\mathrm{x}}$ inhibits further dissolution of $\mathrm{Pt}$ in the high potential region of $0.6-1.5 \mathrm{~V}$ (Figure 5a-c) [123]. Another similar study shows that among the Pt/C catalysts of $2-4 \mathrm{~nm}$, the catalysts with $2 \mathrm{~nm}$ particle size maintained the highest activity after 30,000 ADT in the potential range of 0.6-1.0 V. The authors concluded that high ORR stability can be obtained when the NPs have a narrow particle size distribution and uniformly disperse on the carbon support [124]. Therefore, considering the superior stability of Pt-based intermetallic nanocrystals over $\mathrm{Pt} / \mathrm{C}$ catalyst, it is possible to design small particle size $(<6 \mathrm{~nm})$ NPs for ORR [76,82,125].
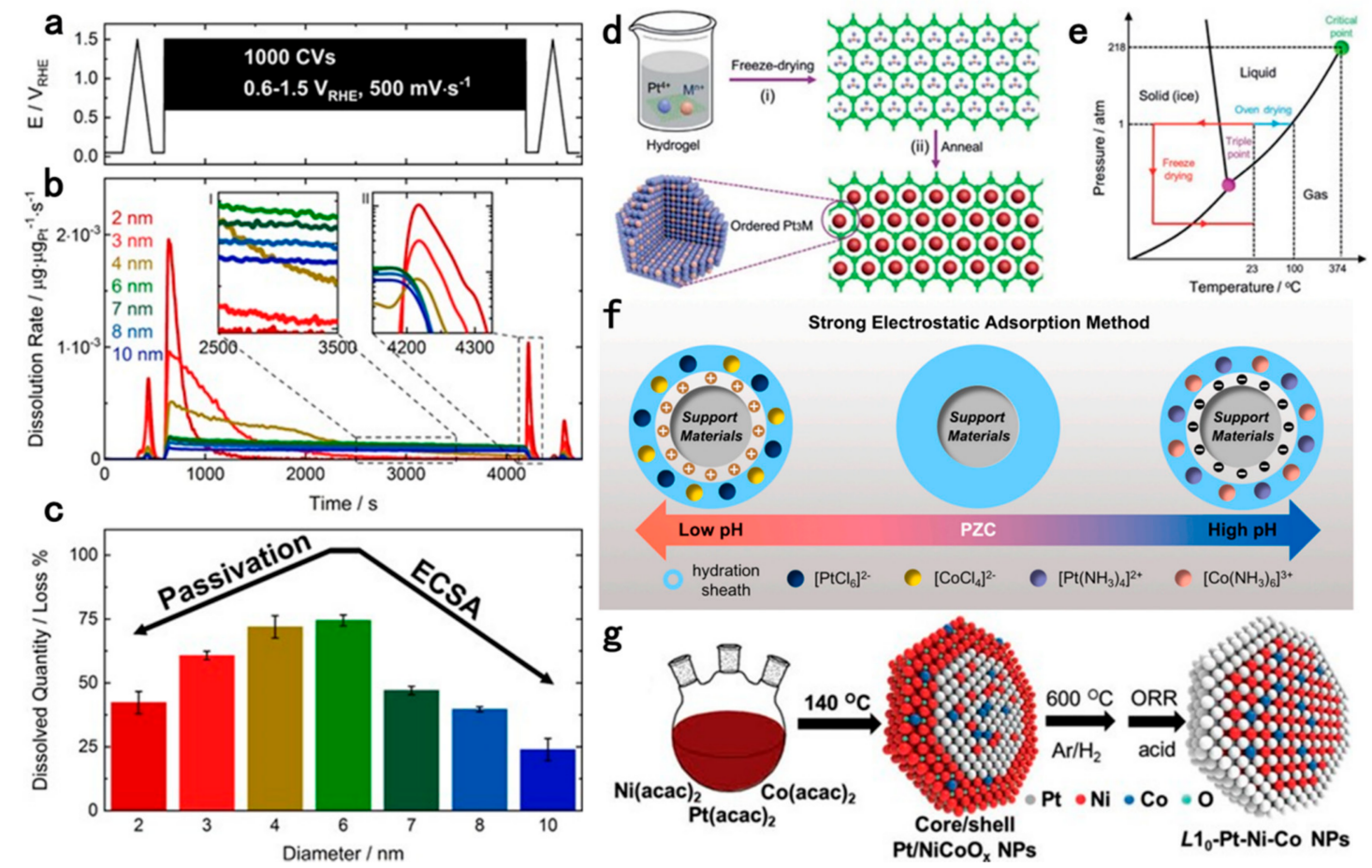

Figure 5. (a) Applied AST of CVs from 0.6 to $1.5 \mathrm{VRHE}$ at $500 \mathrm{mV} \cdot \mathrm{s}^{-1}$ for 1000 cycles preceded and followed by a CV from 0.05 to $1.5 \mathrm{VRHE}$ at $10 \mathrm{mV} \cdot \mathrm{s}^{-1}$. (b) Corresponding mass-normalized dissolution rate of the samples of varied particle size with $b^{\mathrm{I}}$ and $b^{\mathrm{II}}$ insets showing midway dissolution and cathodic peak during reductive hold following the AST. (c) Quantified dissolution during the AST total Pt loss \% (mass-normalized) [123]. Copyright 2020 American Chemical Society. (d) Schematic illustrations of the formation of $\mathrm{Pt}_{3} \mathrm{Mn} / \mathrm{rGO}-\mathrm{HF}$, and the advantages of freeze-drying. (e) Phase diagram of water showing triple point of water [126]. Copyright 2020 Wiley-VCH. (f) Schematic illustration of the strong electrostatic adsorption method for preparing bimetallic PtCo NPs on the support materials at different pH ranges [127]. Copyright 2021 Elsevier. (g) Fabrication of L1 10 -Pt-Ni-Co NPs with Pt-rich shell [128]. Copyright 2019 Wiley-VCH.

Since the formation of intermetallic compounds requires high-temperature treatment, the synthesis of NPs with small particle size often needs confinement measures, which not 
only serves to control the particle size, but also enhances the NP stability by limiting the particle growth during the ORR process. Confinement strategies have been well covered in many works over the past few years $[16,27,109]$. Below only discusses a few of the latest confinement strategies for ORR.

Fully ordered PtFe intermetallic NPs with a particle size of $3.6 \mathrm{~nm}$ are synthesized by Wang's group. In this work, the Fe@C core-shell structure obtained by spray pyrolysis is used as the precursor of Fe element and the reducing agent of $\mathrm{Pt}$, and the ratio of $\mathrm{PtFe}$ is delicately regulated by ferric ions. There is only a little loss of activity after ADT. The excellent stability of the catalysts depends not only on the fully ordered intermetallic structure, but also on the confining effect of the porous carbon support [76]. A more general approach is proposed by Zhang et al. who prepared PtM $(\mathrm{M}=\mathrm{Mn}, \mathrm{Cr}, \mathrm{Fe}, \mathrm{Co}$, etc.) intermetallic NPs with a particle size of about $3 \mathrm{~nm}$. Using the hydrogel interaction of polyvinyl alcohol and graphene oxide (GO) with freeze-drying technique, the authors constructed a three-dimensional porous structure with reduced graphene oxide as carbon support, which ensures the uniform dispersion of NPs and effectively protects them from agglomeration during the formation of the ordered structure induced by high temperature (Figure $5 \mathrm{~d}, \mathrm{e}$ ). This sophisticated design allows the scalable preparation of small particle size catalysts [126]. The same impregnation method is used to synthesize Pt-based intermetallic nanocrystals with particle size less than $3 \mathrm{~nm}$. Instead of adding a confining agent, Ma et al. prepared PtCo intermetallic nanocrystals by strong electrostatic adsorption of the precursor to the carbon support (Figure 5f). Adsorption intensity of the metal precursors to the support is adjusted by changing the $\mathrm{pH}$ value of the impregnation system and the type of metal precursors. Strong adhesion of the metal precursors ensures uniform dispersion of PtCo NPs on the carbon support, thus inhibiting possible atomic migration and sintering during the high-temperature process. The catalyst has a MA of $0.67 \mathrm{~A} / \mathrm{mg}_{\mathrm{Pt}}$, and the activity only decreases by $3 \%$ after 10,000 cycles of ADT. This study provides a new idea for the preparation of ultrafine particle size intermetallic compounds without blocking agents [127].

However, the metal loading of the synthesized catalysts of Ma is only about 10\% [127]. Larger metal loading is usually required to ensure low internal resistance and sufficient mass transfer in practical MEA applications, therefore, it is necessary to develop electrocatalysts with high metal loading associated with small particle size and high dispersion [46]. A series of catalysts with a metal loading up to $37 \%$ are designed by Yoo et al. Bimetallic compounds $\left[\mathrm{M}(\mathrm{bpy})_{3}\right]\left[\mathrm{PtCl}_{6}\right]\left(\mathrm{M}=\mathrm{Fe}, \mathrm{Co}\right.$ or $\mathrm{Ni}$, bpy $=2,2^{\prime}$-bipyridine $)$ are used to fully homogenize the metal precursors, the ligand of bipyridine with negatively charged GO ensures the uniform dispersion of the catalyst, and the $\mathrm{N}$-doped carbon layer formed after pyrolysis protects NPs from agglomeration. SA of $\mathrm{L}_{0}-\mathrm{PtFe}$ catalyst loaded on $\mathrm{rGO}$ is about 19 times higher than that of commercial $\mathrm{Pt} / \mathrm{C}$, while the activity does not decay after 20,000 half-cell ADT cycles [82]. However, in order to guarantee that the active site is not shielded, the $\mathrm{N}$-doped carbon shell needs an additional etching step to remove, which complicates the experimental procedure. Wang et al. introduced $\mathrm{Pt} @ \mathrm{NiCoO}_{x}$ core-shell structure to protect the NPs from agglomeration (Figure $5 \mathrm{~g}$ ). The bifunctional oxide shell is reduced to alloy metal during hydrogen reduction and also provides abundant oxygen vacancies to promote the formation of the intermetallic structure. The as-synthesized catalysts have a particle size of less than $6 \mathrm{~nm}$ and a half-wave potential up to $0.951 \mathrm{~V}$ [128]. Following the same idea, the group have synthesized $\mathrm{L} 1_{0}-\mathrm{PtZn}$ catalysts with particle size less than $4 \mathrm{~nm}$, which also have outstanding ORR performance [129]. From the above works, it is clear that the key to the synthesis of small size NPs lies in the enhanced dispersion of metal precursors and the protection of NPs from agglomeration under high-temperature conditions. Different strategies have their own advantages and disadvantages. We hope that there could be a strategy that couples all the advantages of the above schemes to achieve the high SA while having a large ECSA. 


\subsubsection{Core-Shell Structure}

The core-shell structure has been widely used in the design of fuel cell cathode catalysts [130-134]. Its unique structure not only boosts the ORR activity and stability, but also increases the utilization of $\mathrm{Pt}$ [135]. The enhanced activity of the core-shell structure is mainly from the compressive strain of the Pt-rich shell layer [88]. For intermetallic nanocrystals, the uniform atomic arrangement allows for a thin Pt-skin structure after dealloying treatment. Therefore, the surface Pt atoms can be affected by both the strain effect (within five atomic layers) and the ligand effect (within three atomic layers) [98,101]. Dealloying treatments involve electrochemical dealloying and chemical dealloying. The final morphology of the NPs is dependent on the methods of dealloying and the ordering degree. It has been reported that the partially ordered $\mathrm{PtCu}_{3}$ is a core-shell structure after electrochemical dealloying, while chemical dealloying leads to a sponge structure [136]. Different electrochemical dealloying conditions can also lead to different structures of $\mathrm{NPs}$ [137]. In contrast, the morphology of the fully ordered $\mathrm{L} 1_{0}-\mathrm{PtFe}$ catalysts does not change significantly even after $12 \mathrm{~h}$ of acid treatment at $60{ }^{\circ} \mathrm{C}$ with $0.1 \mathrm{M} \mathrm{HClO}_{4}$. Instead, a two-atomic-layer Pt shell forms on the NP surfaces. This homogeneous Pt shell allows the catalysts to be cycled for 30,000 cycles in MEA at $0.6-0.95 \mathrm{~V}, 80^{\circ} \mathrm{C}$ without significant activity decay [75]. The author also prepared $\mathrm{L}_{0}-\mathrm{PtCo} / \mathrm{Pt}$ core-shell catalysts by a modified method (Figure 6). A high percentage of $\mathrm{PtCo}$ intermetallic structure is maintained due to fully ordered $\mathrm{L} 1_{0}-\mathrm{PtCo}$ structure under $24 \mathrm{~h}$ of perchloric acid treatment. Two to three atomic layers of $\mathrm{Pt}$ are visible on the NP surface. The catalyst has a MA of $0.56 \mathrm{~A} / \mathrm{mg}_{\mathrm{Pt}}$ in the MEA test and the activity decays only $19 \%$ after 30,000 cycles ADT. DFT study shows that the enhancement of the catalyst activity originates from the biaxial strain in the $\mathrm{L} 1_{0^{-}}$ PtCo core. With the reduction in Pt shell thickness from 3 to 1 atomic layer, the overpotential of the dissociative pathway decreases, while the overpotential of the associative pathway increases (Figure 6g,h). This shows the important effect of shell thickness on the ORR, and also emphasizes the important role of synthetic factors such as heating time and post-heating process on the final ORR activity [118].
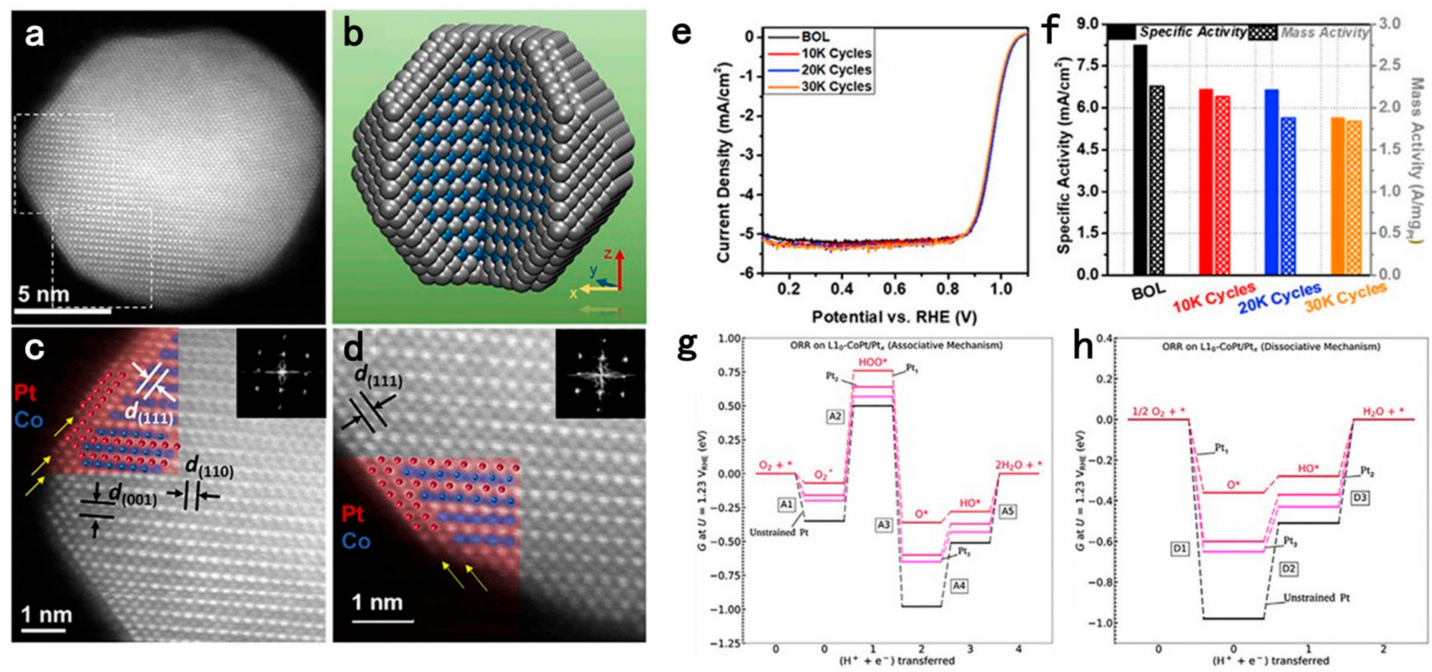

Figure 6. (a) STEM image of $\mathrm{L} 1_{0}-\mathrm{CoPt} / \mathrm{Pt} \mathrm{NPs}$ with 2-3 atomic layers of Pt shell over $\mathrm{L} 1_{0}-\mathrm{CoPt}$ core (darker atom is $\mathrm{Pt}$ and lighter atom is Co), zone axis is the $<1-10>$ direction. Scale bar, $5 \mathrm{~nm}$. (b) Schematic of $\mathrm{L} 1_{0}-\mathrm{CoPt} / \mathrm{Pt} \mathrm{NPs}$ with 2-3 atomic layers of $\mathrm{Pt}$ shell, where the silver-colored atom is $\mathrm{Pt}$ and the blue-colored atom is Co. (c,d) Enlarged sections indicated by dashed squares (top square region, c, bottom square region, $d$ in (a), showing the 2-3 atomic layers of Pt shell (indicated by yellow arrows) and the $\mathrm{L}_{0}-\mathrm{CoPt}$ core, $\mathrm{Pt}$ is colored in red and $\mathrm{Co}$ is colored in blue. Scale bars, $1 \mathrm{~nm}$. (e) ORR polarization curves of $\mathrm{L}_{0}-\mathrm{CoPt} / \mathrm{Pt}$ obtained at BOL and EOL. (f) Specific activity and mass activity of $\mathrm{L} 1_{0}-\mathrm{CoPt} / \mathrm{Pt}$ measured at $0.9 \mathrm{~V}$ (versus RHE) at BOL and EOL (10,000 cycles, 20,000 cycles, and 30,000 cycles). Free energy diagram calculated via DFT method on associative pathway $(\mathrm{g})$ and on dissociative pathway $(\mathbf{h})$ for $\mathrm{L} 1_{0}$-CoPt/Ptx (111) surface (x $=1-3 \mathrm{Pt}$ overlayers) and unstrained Pt (111) surface [118]. Copyright 2019 Elsevier. 
In addition, the core-shell structure of intermetallic NPs can also be obtained by Galvanic placement on ordered structures [138]. Chen et al. synthesized core-shell structure catalysts with $\mathrm{Pt}$ as the shell and $\mathrm{AuCu}$ as the core by depositing $\mathrm{Pt}$ on $\mathrm{AuCu}$ intermetallic NPs. The intermetallic AuCu core ensures a uniform distribution of Pt on its surface relative to the disordered $\mathrm{AuCu}$ core. XPS results suggest that there is less Pt in the oxidation state on the ordered AuCu@Pt relative to the disordered counterpart. This phenomenon can be explained by the XAS results that the electrons in the Au atoms are transferred to the Pt atoms in the surface oxidation state, which lowers the d-band center of Pt and increases the d-band center of Au, thus enhancing the ORR activity [139]. Therefore, it is possible to construct catalysts containing non-Pt or even non-precious metal intermetallic core structures to enhance ORR activity and stability.

\subsubsection{Nitrogen Introduction}

The role of nitrogen in Pt-based catalysts is mainly achieved by forming $\mathrm{M}-\mathrm{N}$ bonds to modulate strain of $\mathrm{Pt}$ shell, or by modifying carbon support through $\mathrm{N}-\mathrm{C}$ or $\mathrm{M}-\mathrm{N}-\mathrm{C}$ ligands. The formation of M-N bonds is mainly achieved by annealing Pt-based NPs under an ammonia atmosphere, while the $\mathrm{M}-\mathrm{N}-\mathrm{C}$ or $\mathrm{N}-\mathrm{C}$ ligands are mainly obtained by pyrolysis of nitrogen-containing compounds. Recent studies have shown that the introduction of $\mathrm{N}$ elements can not only improve ORR activity by increasing the active site density, but also play an important role in ORR stability [140-142].

An N-doped graphitic carbon support with $\mathrm{Co}$ as the core and $\mathrm{N}-\mathrm{C}$ structure as the shell was prepared by Jung et al., using ethylenediamine as the nitrogen source [143]. The Pt is deposited on this support by polyol method, and finally, the combined PtCo intermetallic catalyst is formed by annealing at $5 \% / 95 \% \mathrm{H}_{2} / \mathrm{N}_{2}$ for $2 \mathrm{~h}$. XPS characterization proves that the support comprises a large amount of pyridinic-N. This nitrogen situated on the edge of the graphite plane could provide p-electron into $\pi$ orbitals, which increases the ORR activity [144]. The strong interaction of graphitized carbon and $\mathrm{Pt}$ inhibits carbon oxidation [145]. Combined with the intermetallic structure, the synthesized catalyst ultimately has stable performance under the operating conditions of PEMFCs. The confining strategy with an N-doped carbon shell is also used for the synthesis of Pt-based intermetallic nanocrystals [73]. Recently, Hu et al. synthesized Pt-Fe intermetallic NPs with an N-doped carbon shell by using dicyandiamide as the nitrogen source [125]. This in-situ formed N-doped carbon shell not only disperses the NPs uniformly and prevents the agglomeration of NPs, but also provides a strong anchoring effect to improve the ORR performance at the same time. The prepared O-Pt-Fe@NC/C catalyst exhibits excellent ORR activity and stability, as well as resistance to $\mathrm{CO}, \mathrm{SO}_{x}$ and $\mathrm{PO}_{\mathrm{x}}$ poisoning. Inspired by the excellent catalytic performance of single-atom catalysts (SACs) for ORR, a class of catalysts combining $\mathrm{Pt}$ with SAC was proposed, which possess a large density of active sites [146-148]. Ao et al. introduced a composite catalyst consisting of N-doped carbon support, Fe-N-C catalytic sites and PtFe intermetallic nanocrystals [147]. The catalysts were prepared by depositing Pt NPs on atomically dispersed Fe-N-C structures derived by metal-organic framework (MOF), followed by heat treatment to form core-shell PtFe intermetallic nanocrystals (Figure 7). The porous Fe-N-C structure not only provides more active sites than normal carbon support, but also improves the durability of the composite catalyst by anchoring the PtFe intermetallic nanocrystals during the alloying process. The synthesized catalysts also have good performance in the single-cell test, thus showing that the integrated design is beneficial in the catalytic ORR process [147]. 

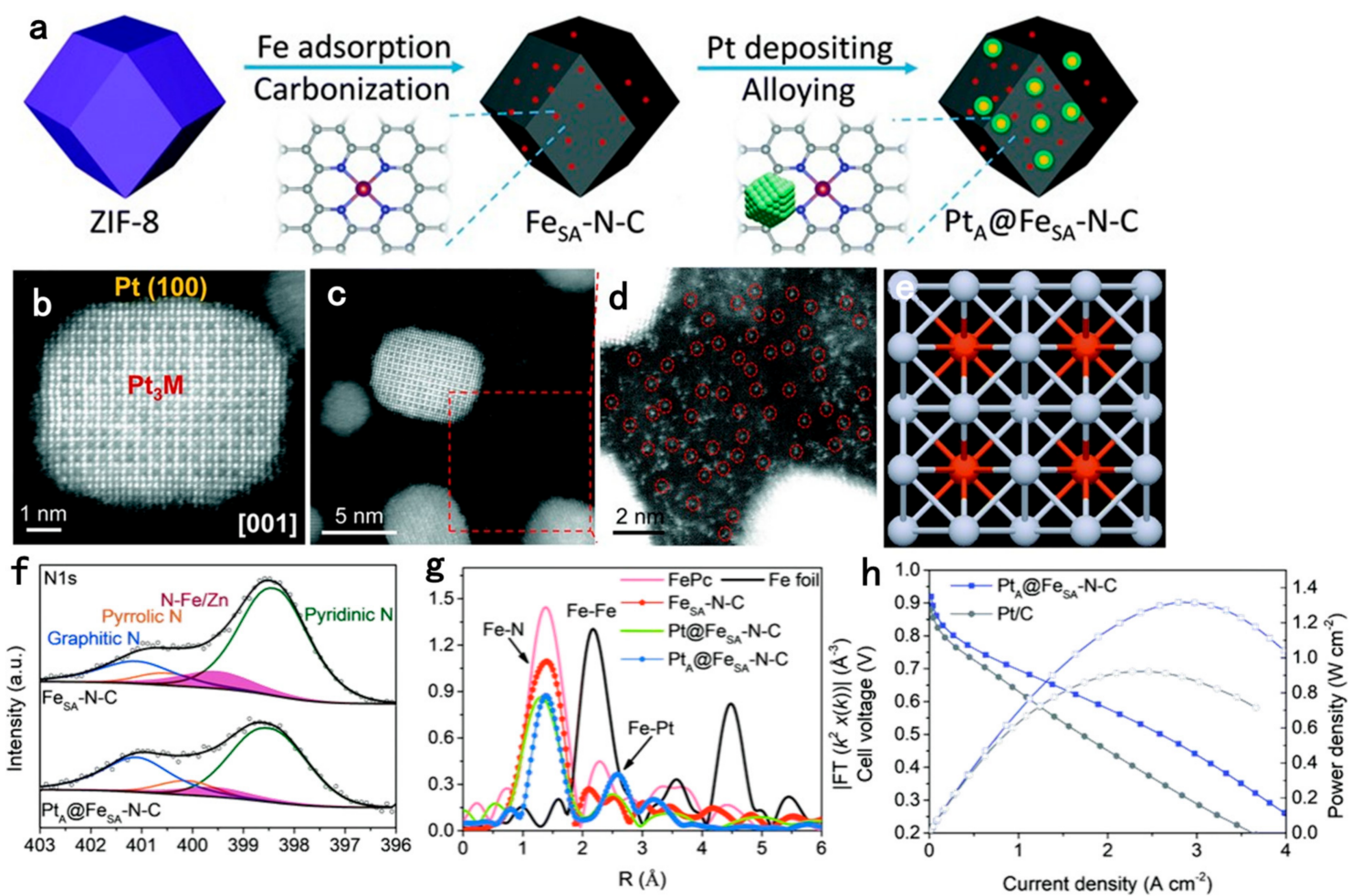

Figure 7. (a) Schematic illustration of the preparation of $\mathrm{Pt}_{\mathrm{A}} @ \mathrm{Fe}_{\mathrm{SA}}-\mathrm{N}-\mathrm{C}$. (b-d) HAADF-STEM images of $\mathrm{Pt}_{\mathrm{A}} @ \mathrm{Fe}_{\mathrm{SA}}-\mathrm{N}-\mathrm{C}$. (e) Crystal structure of ordered $\mathrm{Pt}_{3} \mathrm{M}$ viewed along the [001] zone axis (the red and grey spheres present $\mathrm{M}$ and $\mathrm{Pt}$ atoms, respectively). (f) XPS spectra of $\mathrm{N}$ 1s for $\mathrm{Fe}_{\mathrm{SA}}-\mathrm{N}-\mathrm{C}$ and $\mathrm{Pt}_{\mathrm{A}} @ \mathrm{Fe}_{\mathrm{SA}}-\mathrm{N}-\mathrm{C}$. (g) FT-EXAFS spectra of FesA $-\mathrm{N}-\mathrm{C}, \mathrm{Pt} @ \mathrm{Fe}_{\mathrm{SA}}-\mathrm{N}-\mathrm{C}$, $\mathrm{Pt}_{\mathrm{A}} @ \mathrm{Fe}_{\mathrm{SA}}-\mathrm{N}-\mathrm{C}$ and reference materials at the Fe K-edge. (h) The I-V (solid symbols and lines) and I-P (hollow symbols and dashed lines) curves of the $\mathrm{H}_{2}-\mathrm{O}_{2}$ fuel cell. The cathode loading is $0.13 \mathrm{mg} \mathrm{Pt} / \mathrm{cm}^{2}$; the pressure is 1.0 bar; and the cell temperature is $65^{\circ} \mathrm{C}$ [147]. Copyright 2020 Royal Society of Chemistry.

Recently, a method was reported to induce intermetallic structures by ammonia annealing [149-151]. In this way, $\mathrm{N}$ elements are doped into the metal lattice and trigger the alloy to generate intermetallic nanocrystals with different superstructures, leading to a favorable effect on the ORR performance. Zhao et al. synthesized the PtNi intermetallic nanocrystals by ammonia annealing of PtNi alloy, which is the smallest reported PtNi intermetallic nanocrystals with a particle size of only $4.7 \mathrm{~nm}$ [149]. XRD and EXAFS characterizations demonstrate that the NPs have an ordered structure of Pt plane alternating with $\mathrm{Ni}_{4}-\mathrm{N}$ plane. Electrochemistry characterization demonstrates that the catalysts have a MA of $1.83 \mathrm{~A} / \mathrm{mg}_{\mathrm{Pt}}$, and the MA only decreased by $27 \%$ after 30,000 cycles of ADT. The authors attributed the excellent stability of these catalysts to the formation of the $\mathrm{Ni}_{4}-\mathrm{N}$ structure in synergy with the intermetallic structure, which effectively prevents the dissolution of Ni from the alloy. DFT calculations show that the formation of the intermetallic nanocrystals with the tensile strain introduced by the $\mathrm{N}$ doping optimizes the bonding of the $\mathrm{OH}_{\mathrm{ad}}$ on the Pt surface, enabling efficient electron transfer and thus improving the ORR performance (Figure 8) [149]. The group then reported the $\mathrm{L}_{1}-\mathrm{PtCu}$ catalysts generated under ammonia gas conditions [150]. The $\mathrm{L}_{1}$ structure, which is rhombic distorted on the basis of the face-centered cubic structure, has a stronger ligand effect than the $\mathrm{L} 1_{0}$ structure due to different subsurface atomic arrangements [152]. The MA of the $\mathrm{L} 1_{1}-\mathrm{PtCu}$ catalysts is as high as $1.15 \mathrm{~A} / \mathrm{mg}_{\mathrm{Pt}}$ in the half-cell test, and the ECSA decreased only $6.6 \%$ after 20,000 cycles of ADT. The authors suggested that the pinning effect of the $\mathrm{Cu}-\mathrm{N}$ bond and the $\mathrm{L}_{1}$ structure synergistically enhance the stability of the catalyst, and the excellent activity of $\mathrm{L1}_{1}-\mathrm{PtCu}$ is attributed to the compressive strain effect at the $\mathrm{Cu}$ site due to $\mathrm{N}$ doping [150]. In addition, the ammonia-treated $\mathrm{Pt}_{3} \mathrm{Co}$ intermetallic nanocrystals are also experimentally shown to exhibit superior performance compared 
to commercial $\mathrm{Pt} / \mathrm{C}$ [151]. Liu et al. reported N-doped-ordered $\mathrm{Pt}_{3} \mathrm{Co} \mathrm{NPs}$ loaded on XC-72 carbon supports. Both XPS and EDS characterization suggest successful doping of $\mathrm{N}$. Compared with commercial Pt/C, the MA of N-doped $\mathrm{Pt}_{3} \mathrm{Co} \mathrm{NPs}$ is 2.4 times higher than that of commercial $\mathrm{Pt} / \mathrm{C}$, with only decaying by $21.5 \%$ after 20,000 cycles of ADT at high potentials of $0.6-1.1 \mathrm{~V}$ [151]. Although the mechanism of the contribution of nitrogen in the crystal lattice has not been explored deeply enough, it can be seen that the strategy of doping the metal lattice with non-metallic elements provides a new idea to further improve the ORR performance of Pt-based intermetallic catalysts. Doping other non-metallic elements based on intermetallic structures deserves further exploration.

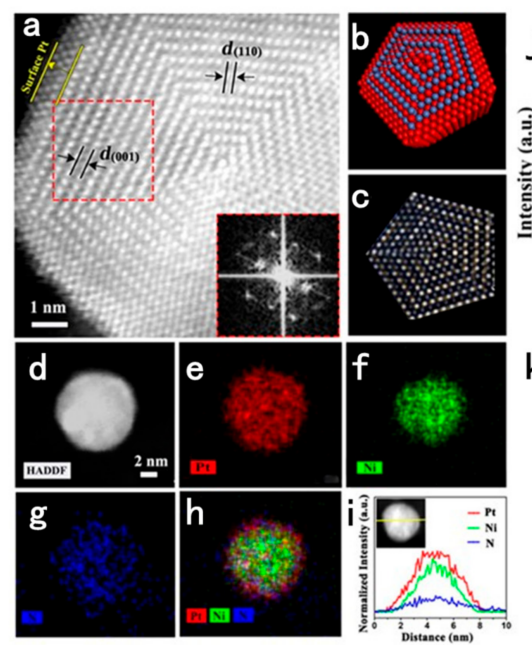

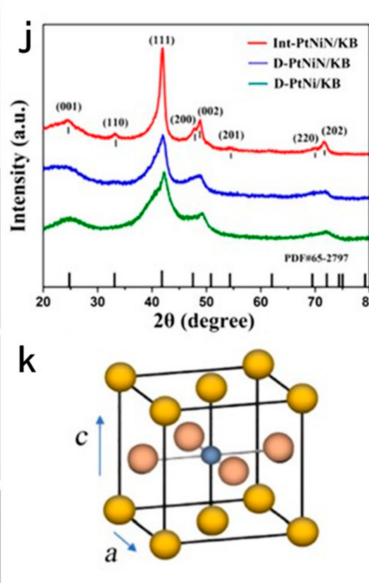

fct : $a=b>c$
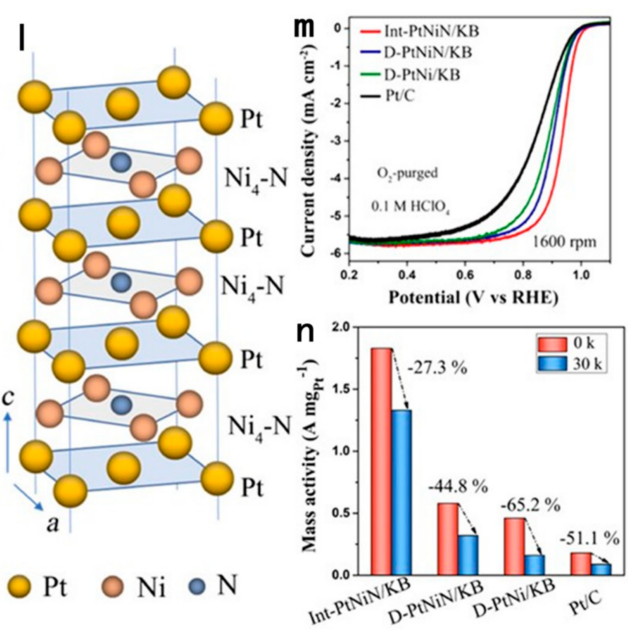

Figure 8. (a) STEM image of Int-PtNiN/KB with three Pt atoms at the surface. The inset shows the corresponding electron diffraction pattern (indicated by red dashed squares). (b) Schematic of Int-PtNiN/KB with three surface Pt atomic layers, where the red-colored atom is Pt and the blue-colored atom is Ni. (c) Simulated HAADF-STEM image of IntPtNiN/KB. (d-h) HAADF-STEM image of a single Int-PtNiN/KB particle along with its EDX mapping. (i) EDX elemental line scan across the single Int-PtNiN/KB particle. (j) XRD patterns of Int-PtNiN/KB (9 h, $\left.\mathrm{NH}_{3}\right), \mathrm{D}-\mathrm{PtNiN} / \mathrm{KB}\left(2 \mathrm{~h}, \mathrm{NH}_{3}\right)$, and $\mathrm{D}-\mathrm{PtNi} / \mathrm{KB}\left(9 \mathrm{~h}, \mathrm{H}_{2} / \mathrm{Ar}\right)$ samples annealed at $560{ }^{\circ} \mathrm{C}$. (k) $\mathrm{L} 1_{0}$-type structure with a nitrogen atom at the center of fct $(\mathrm{N}$ of $\mathrm{Ni}-\mathrm{N}$ is 4). (1) Schematic of the ordering structure alternating $\mathrm{Ni}_{4}-\mathrm{N}$ moieties and Pt planes. (m) ORR polarization curves of commercial Pt/C, D-PtNi/KB, D-PtNiN/KB, and Int-PtNiN/KB in a $0.1 \mathrm{M} \mathrm{HClO}_{4}$ acidic solution (sweep rate $=10 \mathrm{mV} \mathrm{s}{ }^{-1}$ ). (n) MA comparison of Int-PtNiN/KB, D-PtNiN/KB, D-PtNi/KB, and Pt/C before and after 30,000 potential cycles [149]. Copyright 2020 American Chemical Society.

\subsubsection{Ternary Intermetallic Compounds}

This section focuses on the strategies to introduce third functional metal elements in the intermetallic structures for ORR performance enhancement. One is ternary intermetallic strategy to further modulate the adsorption state of the oxygen-containing intermediates on the Pt surface, the other is the doping strategy to enhance the activity or stability of the ORR process.

Since Pt-based intermetallic nanocrystals have fixed stoichiometric ratios, usually 3:1 or 1:1, changing the stoichiometry of NPs usually disrupts the ordered structure of intermetallic compounds. Therefore, to ensure the role of fully ordered structure in the ORR process to enhance stability, the introduction of a third alloying metal element is considered as an effective way to optimize the electronic structure of surface Pt shells to achieve optimal ORR performance. Zhang et al. optimized the surface strain of fct-PtFe/Pt NPs by introducing $\mathrm{Cu}$ to partially replace $\mathrm{Fe}$, and the calculation results show that the $\Delta \mathrm{E}_{\mathrm{O}}$ of the optimized $\mathrm{fct}-\mathrm{PtFeCu} / \mathrm{Pt}$ is $0.22 \mathrm{eV}$, which is close to the optimal ORR $\Delta \mathrm{E}_{\mathrm{O}}$ of $0.2 \mathrm{eV}$. The experimental results confirm that the intermetallic compounds with a ratio of $\mathrm{Pt}: \mathrm{Fe}: \mathrm{Cu}=2: 1: 1$ possesses the highest ORR activity, with a SA approximately 10 times higher than that of the benchmark Pt catalyst [153]. Based on $\mathrm{L1}_{0}$-PtCo intermetallic structural, Li et al. screened the optimal alloy combination of $\mathrm{L1}_{0}-\mathrm{PtCoM}(\mathrm{M}=\mathrm{Mn}, \mathrm{Fe}, \mathrm{Ni}, \mathrm{Cu})$ for catalyzing ORR. They use the 
eigenforce model, which examines the forces created by the presence of adsorbates and how they interact with applied strains, to predict the binding strength of the adsorbate on the $\mathrm{Pt}$ (111) surface due to the two-dimensional (2D) anisotropic compressive strain caused by the $\mathrm{L}_{0}$ intermetallic structures (Figure 9). Among them, the strain effect on $\mathrm{L} 1_{0}-\mathrm{PtCoNi}$ structure is closest to the optimal value. By synthesizing $5 \mathrm{~nm} \mathrm{L1} 1_{0}-\mathrm{PtCoM}$ catalysts, they further experimentally verified that $\mathrm{L} 1_{0}$ - $\mathrm{PtCoNi}$ possesses the highest ORR activity with MA up to $3.1 \mathrm{~A} / \mathrm{mg}_{\mathrm{Pt}}$ and only $15.9 \%$ activity decay after 30,000 cycles of half-cell ADT [154]. This paper combines theory predictions and experiments to demonstrate the special contribution of anisotropic strain effects in the $\mathrm{L} 1_{0}$ structure to the ORR process in the dissociation pathway, and gives prospective guidance on the refinement of intermetallic compounds in the ORR catalyst structure.

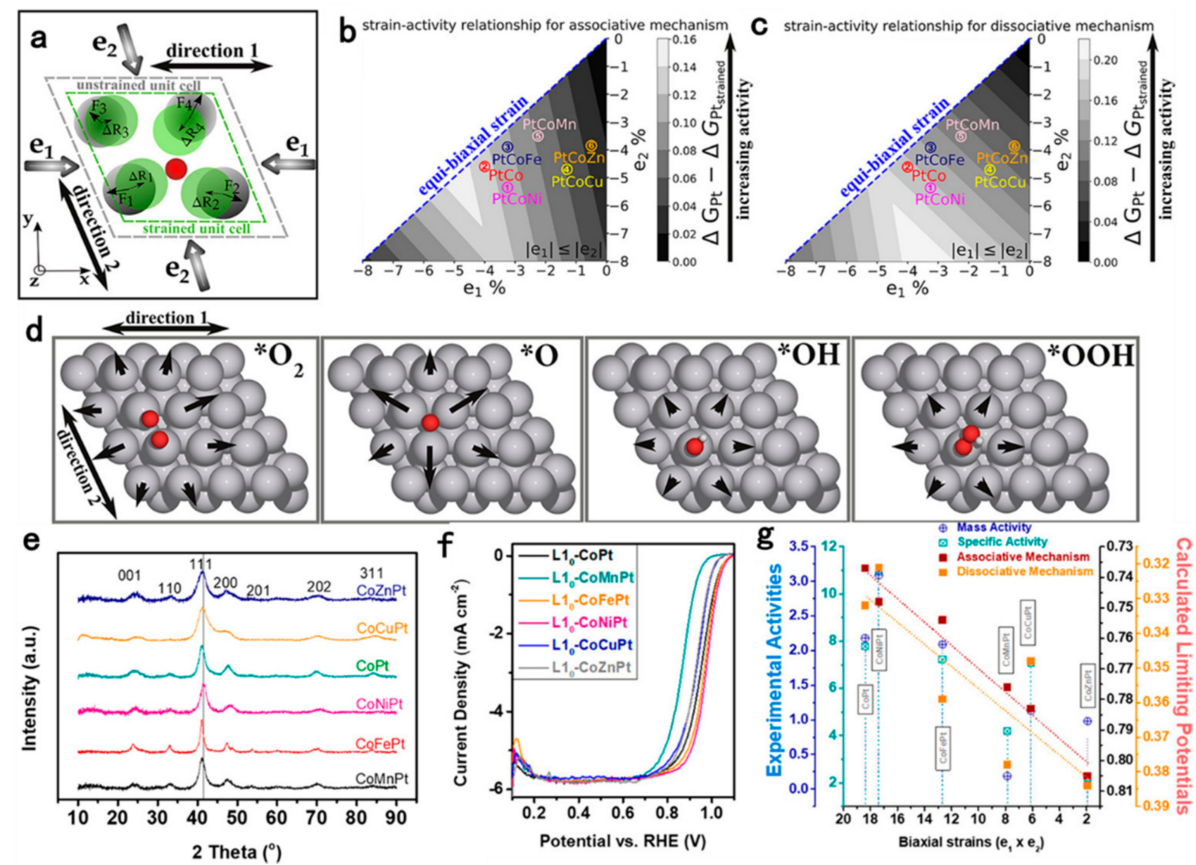

Figure 9. (a) Illustration of the in-plane components of the adsorbate-induced eigenforces and the displacement caused by an applied strain. Calculated 2D volcano plots of strained $\mathrm{Pt}$ (111) surfaces using the eigenforce model for $(\mathbf{b})$ the dissociative mechanism and (c) the associative mechanism. The CoMPt (circles) represents $\mathrm{L} 1_{0}$-alloyed Pt (111) surfaces in the DFT-optimized lattice constants of their respective ternary $\mathrm{L}_{0}$-CoMPt alloy. $\mathrm{e}_{1}$ and $\mathrm{e}_{2}$ represent the percent strains experienced by the $\mathrm{Pt}$ (111) surface in directions 1 and 2, respectively. The numbers on the volcano rank the $\mathrm{L} 1_{0}$ strained surfaces in terms of experimentally observed specific activity (SA). (d) In-plane components of eigenforces induced by the geometrically optimized adsorbates on the unstrained $\mathrm{Pt}$ (111) surface. (e) XRD patterns of as-synthesized $\mathrm{L}_{0}$-CoMPt alloy. (f) LSV curves of C-L1 $1_{0}-\mathrm{CoPt}$ and $\mathrm{L} 1_{0}-\mathrm{CoMPt}$ NPs $(\mathrm{M}=\mathrm{Mn}, \mathrm{Fe}, \mathrm{Co}, \mathrm{Ni}, \mathrm{Cu}, \mathrm{Zn})$ collected in $\mathrm{O}_{2}$-saturated $0.1 \mathrm{M} \mathrm{HClO}_{4}$ at room temperature. (g) Plot of experimental activities (MA and SA) and calculated limiting potential of C-L1 $10-\mathrm{CoPt}$ and C-L1 $1_{0}$-CoMPt catalysts [154]. Copyright 2020 American Chemical Society.

The excellent activity of Pt-Ni-Co-ordered catalysts was reported before $\mathrm{Li}$ et al. For example, the $\mathrm{Pt}_{2} \mathrm{NiCo}$ catalysts with an average particle size of $7.5 \mathrm{~nm}$ synthesized using the molten salts method reported by Lokanathan et al. in 2018, which have a MA of $0.931 \mathrm{~A} / \mathrm{mg}_{\mathrm{Pt}}$. The $\mathrm{L}_{0}-\mathrm{PtNi}_{0.8} \mathrm{Co}_{0.2}$ catalysts with an average particle size of $5 \mathrm{~nm}$ synthesized by Wang et al. in 2019 with a MA as high as $2.28 \mathrm{~A} / \mathrm{mg}_{\mathrm{Pt}}[70,128]$. This further experimentally demonstrates that the $\mathrm{L} 1_{0} \mathrm{Pt}-\mathrm{Co}-\mathrm{Ni}$ system has a high intrinsic ORR activity. In addition, ternary intermetallic compounds such as $\mathrm{PtCuCo}, \mathrm{PtFeNi}$, and $\mathrm{PtCuNi}$ have also been experimentally demonstrated to have excellent ORR performance, but the mechanisms of activity enhancement still need to be further explored [155-158]. 
Doping a trace amount of metal elements also brings great benefits to the intermetallic nanocrystals in ORR catalysis. Liang et al. increased the half-wave potential from $0.940 \mathrm{~V}$ to $0.953 \mathrm{~V}$ and the MA from $1.17 \mathrm{~A} / \mathrm{mg}_{\mathrm{Pt}}$ to $2.21 \mathrm{~A} / \mathrm{mg}_{\mathrm{Pt}}$ by doping a small amount of $\mathrm{W}$ element in the $\mathrm{L} 1_{0}-\mathrm{PtC}$ lattice. Structural characterization and DFT calculations show that the $\mathrm{W}$ doping not only stabilizes the ordered structure, but also optimizes the binding energy of Pt surface to oxygen-containing intermediates by adjusting the Pt-Pt distance [159]. It has been shown that the introduction of Au element can enhance the ORR stability of Pt NPs by increasing the oxidation potential of the system, compensating for defective sites, stabilizing the charge transfer, and stabilizing the non-Pt metals [160-164]. By doping Au on fct-PtFe structure, both Zhu and He et al. further demonstrated experimentally that the conclusion also applies to intermetallic nanocrystals $[165,166]$. Ternary strategies have been widely used for Pt-based catalysts [167]. Despite the fact that many ternary strategies of intermetallic compounds have not yet been developed due to the limitations of alloy species and ratios, it is believed that the ternary intermetallic nanocrystals will bring more possibilities for the ORR performance, considering the current wide application of binary alloy catalysts in industry.

\subsubsection{Intermetallic Compounds of Pt with Non-Fenton Activity Elements}

In recent years, intermetallic NPs such as $\mathrm{PtFe}, \mathrm{PtCo}$, and $\mathrm{PtNi}$ have shown excellent ORR activity and stability in PEMFCs. However, these easily oxidized metals, especially $\mathrm{Fe}$, generate Fenton reagents with hydrogen peroxide, an intermediate of the ORR, to further damage the proton exchange membrane and catalyst layer. Therefore, alloying elements with non-Fenton activity should be developed in the ORR catalytic process. Liang et al. reported PtZn intermetallic nanocrystals with a particle size of $4 \mathrm{~nm}$. The authors demonstrate that element $\mathrm{Zn}$ can effectively inhibit the formation of reactive oxygen species (ROS) and thus the proceeding of Fenton reaction by measuring the absorbance of Fenton reagent. In the MEA test, the $\mathrm{MA}$ of $\mathrm{PtZn}$ catalysts is $0.52 \mathrm{~A} / \mathrm{mg}_{\mathrm{Pt}}$, with only a $16.6 \%$ reduction in activity after 30,000 cycles of ADT. DFT calculations show that the biaxial strain of the $\mathrm{L}_{0}$ intermetallic structure enhances the ORR activity, while the inhibitory effect of Fenton reaction and high vacancy formation energy of the Zn element enhances the MEA stability [129]. Wang et al. prepared $\mathrm{Pt}_{3}$ In intermetallic catalysts with particle size less than $3 \mathrm{~nm}$, which is the smallest intermetallic NPs reported so far. After acid treatment, the alloying effect of PtIn core makes the catalyst possess excellent ORR performance, with negligible decay of structure and activity after the 20,000 cycles ADT. The DFT calculations demonstrate that the introduction of In atoms can also optimize the oxygen adsorption energy on the NP surface, which further enhances the ORR activity of the catalyst [168]. Its stability is even better than that of the conventional ORR catalysts such as PtFe, $\mathrm{PtCo}$ and $\mathrm{PtNi}$ NPs in terms of the MEA test. Therefore, Pt and non-Fe, Co, Ni, Cu intermetallic NPs have promising applications in the field of ORR catalysts.

\subsection{Remark}

In this section, we discuss some strategies of Pt-based intermetallic nanocrystals on ORR performance. Some of those catalyst properties are listed in Table 1. Although the catalytic performance mainly depends on the intermetallic NPs, the role of the support cannot be neglected. The catalytic reaction is a very delicate process in where each factor ultimately affects the catalytic activity. Catalysts with the same alloy component exhibit completely different activities under different supports and preparation methods. In fact, the preparation method and the support are the key factors leading to the successful synthesis of intermetallic compounds and the improvement of catalyst activity and stability. For example, catalysts synthesized in-situ on supports are more stable than those synthesized ex-situ, and graphene is more stable than amorphous carbon. However, intermetallic NPs on graphene support require confining methods, while the amorphous carbon support used for $\mathrm{Pt}_{3}$ In catalysts can generate intermetallic NPs with the smallest particle size reported so far without the addition of any confinement agent. Therefore, new NP-support combinations with high ORR performance are expected as more supports are developed. 
Table 1. Catalytic properties of Pt-based intermetallic nanocrystals in oxygen reduction reaction.

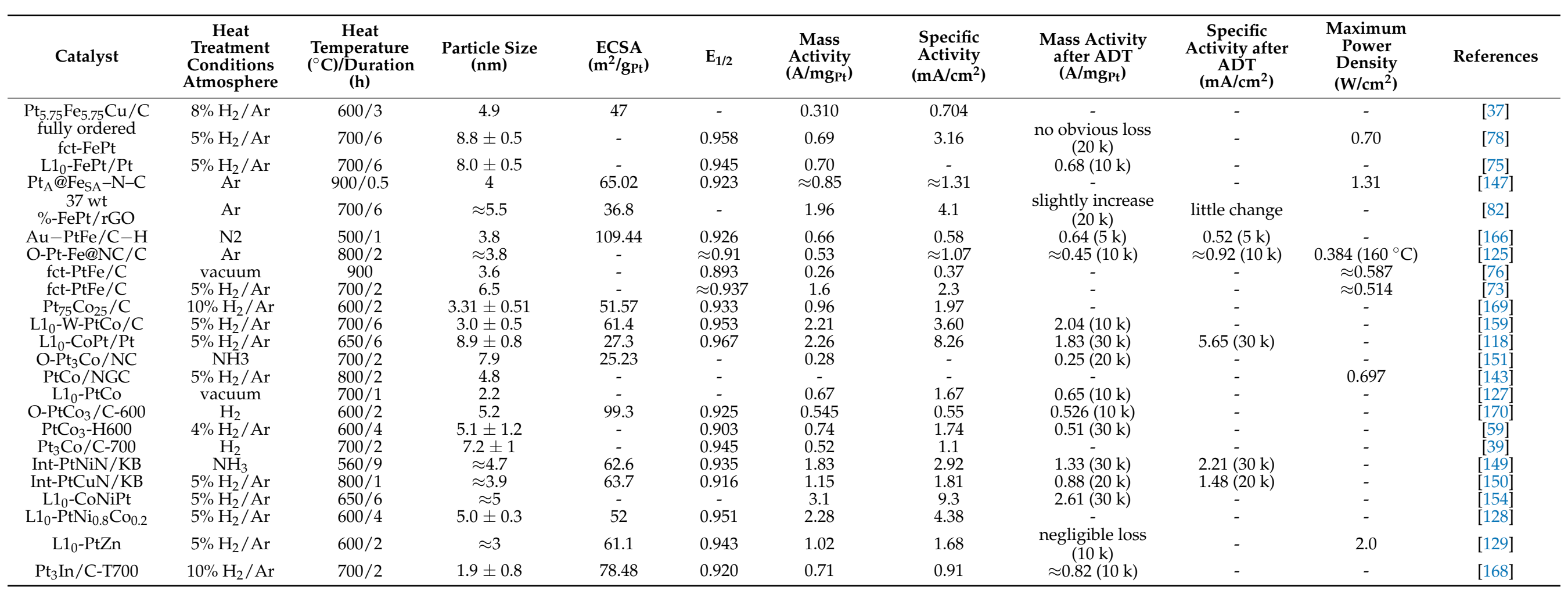


Moreover, the mechanism of some enhancement strategies is still unclear, otherwise, the catalyst with optimal performance should have been discovered, yet it was not. For example, the uncertainty of the N-doping strain effect. New descriptors hence should be established.

Finally, the design of ORR catalysts needs to consider the actual MEA application. We should find the factors that have the most influence on the MEA activity rather than on the RDE activity. In addition, some factors have been identified as having much influence on the catalyst performance, although the current means cannot fully deconvolute the actual contribution of each factor. For example, the alloying elements of Pt-based catalysts, such as $\mathrm{Co}$ and $\mathrm{Ni}$, are more stable than $\mathrm{Fe}$ and $\mathrm{Cu}$ when alloyed with $\mathrm{Pt}$, because $\mathrm{Fe}$ and $\mathrm{Cu}$ elements damage the MEA system more severely during the actual fuel cell utilization. Metal loading is also another important indicator of the performance of MEA. In the cathode, if the metal loading is low $(<20 \%)$, it will increase the thickness of the catalyst layer. This will slow down the mass transfer rate and increase the internal resistance of the cell.

\section{Summary and Outlook}

In this review, we present a comprehensive understanding of Pt-based intermetallic nanocrystals, and summarize the key points of synthesis of Pt-based nanometallic intermetallic nanocrystals, especially the problems that should be paid attention to during the heat treatment and the countermeasures to cope with them, as well as their applications in ORR catalysis in recent years. Various strategies have been implemented to enhance the activity and especially the stability of the catalysts, all of which have shown a significant improvement in performance relative to pure Pt catalysts. However, only a small number of catalysts can actually meet the practical performance demand. The reason is that the existing catalytic theories do not fully cover the origin of the intrinsic activity of the ORR. Moreover, the existing test methods cannot capture the dynamic changes of the catalysts during the reaction process. Finally, different groups use different single-cell test parameters, so even for the same catalyst, the results vary from group to group. Therefore, the following improvements are needed to address these issues, such as realistic computational models to gain insight into the nature of ORR catalysis, protocols, advanced in situ/operando characterizations, and transition from RDE to single-cell testing. As fuel cells become more and more attractive, the various needs and problems encountered in the practical process will also promote the development of fuel cell catalyst technology. It is believed that fuel cells will be widely applied in daily life in the near future.

Author Contributions: Conceptualization, Q.C.; investigation, P.G.; writing-original draft preparation, P.G.; writing-review and editing, Q.C. and H.Z.; supervision, M.P., Q.C. and H.Z.; project administration, M.P., Q.C.and H.Z.; funding acquisition, Q.C. and H.Z. All authors have read and agreed to the published version of the manuscript.

Funding: This research was funded by BRICS STI Framework Programme, grant number 51961145107", the National Natural Science Foundation of China, grant number U1705253, 21975017 and 21776014, the Beijing Natural Science Foundation, grant number Z200012 and 2202052, National Natural Science Foundation of China, grant number 92061125, and Hebei Natural Science Foundation, grant number B2020103043.

Conflicts of Interest: The authors declare no conflict of interest.

\section{References}

1. Debe, M.K. Electrocatalyst approaches and challenges for automotive fuel cells. Nature 2012, 486, 43-51. [CrossRef]

2. Yoshida, T.; Kojima, K. Toyota MIRAI Fuel Cell Vehicle and Progress toward a Future Hydrogen Society. Electrochem. Soc. Interface 2015, 24, 45-49. [CrossRef]

3. Vojislav, N.M.M.; Stamenkovic, R. Tailored High-Performance Low-Platinum-Group-Metal Alloy Cathode Catalysts; Argonne National Laboratory: Argonne, IL, USA, 2019.

4. Thompson, S.T.; James, B.D.; Huya-Kouadio, J.M.; Houchins, C.; DeSantis, D.A.; Ahluwalia, R.; Wilson, A.R.; Kleen, G.; Papageorgopoulos, D. Direct hydrogen fuel cell electric vehicle cost analysis: System and high-volume manufacturing description, validation, and outlook. J. Power Sources 2018, 399, 304-313. [CrossRef] 
5. Song, C.; Zhang, J. Electrocatalytic Oxygen Reduction Reaction. In PEM Fuel Cell Electrocatalysts and Catalyst Layers: Fundamentals and Applications; Zhang, J., Ed.; Springer: London, UK, 2008; pp. 89-134.

6. Wang, X.X.; Swihart, M.T.; Wu, G. Achievements, challenges and perspectives on cathode catalysts in proton exchange membrane fuel cells for transportation. Nat. Catal. 2019, 2, 578-589. [CrossRef]

7. Banham, D.; Ye, S. Current Status and Future Development of Catalyst Materials and Catalyst Layers for Proton Exchange Membrane Fuel Cells: An Industrial Perspective. ACS Energy Lett. 2017, 2, 629-638. [CrossRef]

8. Stamenkovic, V.R.; Mun, B.S.; Arenz, M.; Mayrhofer, K.; Lucas, C.; Wang, G.; Ross, P.N.; Markovic, N.M. Trends in electrocatalysis on extended and nanoscale Pt-bimetallic alloy surfaces. Nat. Mater. 2007, 6, 241-247. [CrossRef]

9. Jayasayee, K.; Van Veen, J.R.; Manivasagam, T.G.; Celebi, S.; Hensen, E.J.; De Bruijn, F.A. Oxygen reduction reaction (ORR) activity and durability of carbon supported PtM (Co, Ni, Cu) alloys: Influence of particle size and non-noble metals. Appl. Catal. B Environ. 2012, 111-112, 515-526. [CrossRef]

10. Neyerlin, K.C.; Srivastava, R.; Yu, C.; Strasser, P. Electrochemical activity and stability of dealloyed Pt-Cu and Pt-Cu-Co electrocatalysts for the oxygen reduction reaction (ORR). J. Power Sources 2009, 186, 261-267. [CrossRef]

11. Li, J.; Sun, S. Intermetallic Nanoparticles: Synthetic Control and Their Enhanced Electrocatalysis. Acc. Chem. Res. 2019, 52, 2015-2025. [CrossRef] [PubMed]

12. Gamler, J.T.L.; Ashberry, H.M.; Skrabalak, S.E.; Koczkur, K.M. Random Alloyed versus Intermetallic Nanoparticles: A Comparison of Electrocatalytic Performance. Adv. Mater. 2018, 30, e1801563. [CrossRef]

13. Luo, M.; Sun, Y.; Wang, L.; Guo, S. Tuning Multimetallic Ordered Intermetallic Nanocrystals for Efficient Energy Electrocatalysis. Adv. Energy Mater. 2016, 7, 1602073. [CrossRef]

14. Pavlišič, A.; Jovanovič, P.; Šelih, V.S.; Šala, M.; Bele, M.; Dražić, G.; Arčon, I.; Hocevar, S.B.; Kokalj, A.; Hodnik, N.; et al. Atomically Resolved Dealloying of Structurally Ordered Pt Nanoalloy as an Oxygen Reduction Reaction Electrocatalyst. ACS Catal. 2016, 6, 5530-5534. [CrossRef]

15. Yan, Y.; Du, J.; Gilroy, K.D.; Yang, D.; Xia, Y.; Zhang, H. Intermetallic Nanocrystals: Syntheses and Catalytic Applications. Adv. Mater. 2017, 29, 1605997. [CrossRef] [PubMed]

16. Xiao, W.; Lei, W.; Gong, M.; Xin, H.; Wang, D. Recent Advances of Structurally Ordered Intermetallic Nanoparticles for Electrocatalysis. ACS Catal. 2018, 8, 3237-3256. [CrossRef]

17. Zhang, J.-M.; Shen, L.; Jiang, Y.; Sun, S.-G. Random alloy and intermetallic nanocatalysts in fuel cell reactions. Nanoscale 2020, 12, 19557-19581. [CrossRef] [PubMed]

18. Antolini, E. Alloy vs. intermetallic compounds: Effect of the ordering on the electrocatalytic activity for oxygen reduction and the stability of low temperature fuel cell catalysts. Appl. Catal. B Environ. 2017, 217, 201-213. [CrossRef]

19. Furukawa, S.; Komatsu, T. Intermetallic Compounds: Promising Inorganic Materials for Well-Structured and Electronically Modified Reaction Environments for Efficient Catalysis. ACS Catal. 2016, 7, 735-765. [CrossRef]

20. Rößner, L.; Armbrüster, M. Electrochemical Energy Conversion on Intermetallic Compounds: A Review. ACS Catal. 2019, 9, 2018-2062. [CrossRef]

21. Calle-Vallejo, F.; Tymoczko, J.; Colic, V.; Vu, Q.H.; Pohl, M.D.; Morgenstern, K.; Loffreda, D.; Sautet, P.; Schuhmann, W.; Bandarenka, A.S. Finding optimal surface sites on heterogeneous catalysts by counting nearest neighbors. Science 2015, 350, 185-189. [CrossRef] [PubMed]

22. Antolini, E. Iron-containing platinum-based catalysts as cathode and anode materials for low-temperature acidic fuel cells: A review. RSC Adv. 2015, 6, 3307-3325. [CrossRef]

23. Potekaev, A.I.; Kulagina, V.V.; Chaplygina, A.A.; Starostenkov, M.D.; Klopotov, A.A. Structural-Phase Transformations in the Cu3Pt5 Alloy During Atomic Ordering. Russ. Phys. J. 2013, 56, 620-629. [CrossRef]

24. Cava, R.J.; Takagi, H.; Batlogg, B.; Zandbergen, H.W.; Krajewski, J.J.; Peck, W.F.; van Dover, R.B.; Felder, R.J.; Siegrist, T.; Mizuhashi, K.; et al. Superconductivity at $23 \mathrm{~K}$ in yttrium palladium boride carbide. Nature 1994, 367, 146-148. [CrossRef]

25. Kirchheim, R.; Mütschele, T.; Kieninger, W.; Gleiter, H.; Birringer, R.; Koblé, T. Hydrogen in amorphous and nanocrystalline metals. Mater. Sci. Eng. 1988, 99, 457-462. [CrossRef]

26. Cortie, M.B.; Kealley, C.S.; Bhatia, V.; Thorogood, G.J.; Elcombe, M.M.; Avdeev, M. High temperature transformations of the Au7Cu5Al4 shape-memory alloy. J. Alloy. Compd. 2011, 509, 3502-3508. [CrossRef]

27. Williams, B.P.; Qi, Z.; Huang, W.; Tsung, C.-K. The impact of synthetic method on the catalytic application of intermetallic nanoparticles. Nanoscale 2020, 12, 18545-18562. [CrossRef]

28. Yang, Y.; Wei, M. Intermetallic compound catalysts: Synthetic scheme, structure characterization and catalytic application. J. Mater. Chem. A 2019, 8, 2207-2221. [CrossRef]

29. Marakatti, V.S.; Peter, S.C. Synthetically tuned electronic and geometrical properties of intermetallic compounds as effective heterogeneous catalysts. Prog. Solid State Chem. 2018, 52, 1-30. [CrossRef]

30. Sun, S.; Murray, C.B.; Weller, D.; Folks, L.; Moser, A. Monodisperse FePt Nanoparticles and Ferromagnetic FePt Nanocrystal Superlattices. Science 2000, 287, 1989-1992. [CrossRef] [PubMed]

31. Wang, X.X.; Sokolowski, J.; Liu, H.; Wu, G. Pt alloy oxygen-reduction electrocatalysts: Synthesis, structure, and property. Chin. J. Catal. 2020, 41, 739-755. [CrossRef]

32. Guan, J.; Yang, S.; Liu, T.; Yu, Y.; Niu, J.; Zhang, Z.; Wang, F. Intermetallic FePt@PtBi Core-Shell Nanoparticles for Oxygen Reduction Electrocatalysis. Angew. Chem. 2021, accepted. 
33. Zhang, J.; Zhang, L.; Cui, Z. Strategies to enhance the electrochemical performances of Pt-based intermetallic catalysts. Chem. Commun. 2020, 57, 11-26. [CrossRef] [PubMed]

34. Kim, H.Y.; Kim, J.Y.; Joo, S.H. Pt-based Intermetallic Nanocatalysts for Promoting the Oxygen Reduction Reaction. Bull. Korean Chem. Soc. 2021, 42, 724-736. [CrossRef]

35. Han, X.-F.; Batool, N.; Wang, W.-T.; Teng, H.-T.; Zhang, L.; Yang, R.; Tian, J.-H. Templated-Assisted Synthesis of Structurally Ordered Intermetallic $\mathrm{Pt}_{3} \mathrm{Co}$ with Ultralow Loading Supported on 3D Porous Carbon for Oxygen Reduction Reaction. ACS Appl. Mater. Interfaces 2021, 13, 37133-37141. [CrossRef] [PubMed]

36. Cao, J.; Cao, H.; Wang, F.; Zhu, H. Fully ordered L10-PtCoAu electrocatalyst derived from PtAu@CoO precursor with enhanced performance for oxygen reduction reaction. Electrochim. Acta 2021, 384, 138266. [CrossRef]

37. Chen, L.; Bock, C.; Mercier, P.; MacDougall, B. Ordered alloy formation for $\mathrm{Pt}_{3} \mathrm{Fe} / \mathrm{C}, \mathrm{PtFe} / \mathrm{C}$ and $\mathrm{Pt}_{5.75} \mathrm{Fe}_{5.75} \mathrm{Cuy}_{/} \mathrm{CO}_{2}$-reduction electro-catalysts. Electrochim. Acta 2012, 77, 212-224. [CrossRef]

38. Hong, Y.; Kim, H.J.; Yang, D.; Lee, G.; Nam, K.M.; Jung, M.-H.; Kim, Y.-M.; Choi, S.-I.; Seo, W.S. Facile synthesis of fully ordered L10-FePt nanoparticles with controlled Pt-shell thicknesses for electrocatalysis. Nano Res. 2017, 10, 2866-2880. [CrossRef]

39. Wang, D.; Xin, H.; Hovden, R.; Wang, H.; Yu, Y.; Muller, D.; Disalvo, F.J.; Abruña, H.D. Structurally ordered intermetallic platinum-cobalt core-shell nanoparticles with enhanced activity and stability as oxygen reduction electrocatalysts. Nat. Mater. 2012, 12, 81-87. [CrossRef] [PubMed]

40. Kuroki, H.; Tamaki, T.; Matsumoto, M.; Arao, M.; Kubobuchi, K.; Imai, H.; Yamaguchi, T. Platinum-Iron-Nickel Trimetallic Catalyst with Superlattice Structure for Enhanced Oxygen Reduction Activity and Durability. Ind. Eng. Chem. Res. 2016, 55, 11458-11466. [CrossRef]

41. Mezzavilla, S.; Baldizzone, C.; Swertz, A.-C.; Hodnik, N.; Pizzutilo, E.; Polymeros, G.; Keeley, G.P.; Knossalla, J.; Heggen, M.; Mayrhofer, K.J.J.; et al. Structure-Activity-Stability Relationships for Space-Confined PtxNiy Nanoparticles in the Oxygen Reduction Reaction. ACS Catal. 2016, 6, 8058-8068. [CrossRef]

42. Saedy, S.; Palagin, D.; Safonova, O.; Van Bokhoven, J.A.; Khodadadi, A.A.; Mortazavi, Y. Understanding the mechanism of synthesis of Pt3Co intermetallic nanoparticlesviapreferential chemical vapor deposition. J. Mater. Chem. A 2017, 5, 24396-24406. [CrossRef]

43. Cai, Y.; Gao, P.; Wang, F.; Zhu, H. Carbon supported chemically ordered nanoparicles with stable Pt shell and their superior catalysis toward the oxygen reduction reaction. Electrochim. Acta 2017, 245, 924-933. [CrossRef]

44. Kim, J.; Lee, Y.; Sun, S. Structurally Ordered FePt Nanoparticles and Their Enhanced Catalysis for Oxygen Reduction Reaction. J. Am. Chem. Soc. 2010, 132, 4996-4997. [CrossRef] [PubMed]

45. Feng, Q.; Zhao, S.; Dingsheng, W.; Tian, S.; Gu, L.; Wen, X.; Chen, C.; Peng, Q.; Wang, D.; Li, Y. Strain Engineering to Enhance the Electrooxidation Performance of Atomic-Layer Pt on Intermetallic Pt ${ }_{3}$ Ga. J. Am. Chem. Soc. 2018, 140, 2773-2776. [CrossRef] [PubMed]

46. Xiong, Y.; Xiao, L.; Yang, Y.; Disalvo, F.J.; Abruña, H.D. High-Loading Intermetallic Pt ${ }_{3}$ Co/C Core-Shell Nanoparticles as Enhanced Activity Electrocatalysts toward the Oxygen Reduction Reaction (ORR). Chem. Mater. 2018, 30, 1532-1539. [CrossRef]

47. Yang, T.; Cui, C.; Rong, H.; Zhang, J.; Wang, D. Recent Advances in Platinum-based Intermetallic Nanocrystals: Controlled Synthesis and Electrocatalytic Applications. Acta Phys. Chim. Sin. 2020, 2003047. [CrossRef]

48. Rong, C.-B.; Li, D.; Nandwana, V.; Poudyal, N.; Ding, Y.; Wang, Z.L.; Zeng, H.; Liu, J.P. Size-Dependent Chemical and Magnetic Ordering inL10-FePt Nanoparticles. Adv. Mater. 2006, 18, 2984-2988. [CrossRef]

49. Sato, K. Magnetic nanoparticles: When atoms move around. Nat. Mater. 2009, 8, 924-925. [CrossRef]

50. Alloyeau, D.; Ricolleau, C.; Mottet, C.; Oikawa, T.; Langlois, C.; Le Bouar, Y.; Braidy, N.; Loiseau, A. Size and shape effects on the order-disorder phase transition in CoPt nanoparticles. Nat. Mater. 2009, 8, 940-946. [CrossRef]

51. Ngai, K.L.; Magill, J.H.; Plazek, D.J. Flow, diffusion and crystallization of supercooled liquids: Revisited. J. Chem. Phys. 2000, 112, 1887-1892. [CrossRef]

52. Goodman, E.D.; Schwalbe, J.A.; Cargnello, M. Mechanistic Understanding and the Rational Design of Sinter-Resistant Heterogeneous Catalysts. ACS Catal. 2017, 7, 7156-7173. [CrossRef]

53. Chi, M.; Wang, C.; Lei, Y.; Wang, G.; Li, D.; More, K.; Lupini, A.; Allard, L.F.; Markovic, N.M.; Stamenkovic, V.R. Surface faceting and elemental diffusion behaviour at atomic scale for alloy nanoparticles during in situ annealing. Nat. Commun. 2015, 6, 8925. [CrossRef]

54. Dai, Z.R.; Sun, A.S.; Wang, Z.L. Phase Transformation, Coalescence, and Twinning of Monodisperse FePt Nanocrystals. Nano Lett. 2001, 1, 443-447. [CrossRef]

55. Chen, H.; Wang, G.; Gao, T.; Chen, Y.; Liao, H.-G.; Guo, X.; Li, H.; Liu, R.; Dou, M.; Nan, S.; et al. Effect of Atomic Ordering Transformation of PtNi Nanoparticles on Alkaline Hydrogen Evolution: Unexpected Superior Activity of the Disordered Phase. J. Phys. Chem. C 2020, 124, 5036-5045. [CrossRef]

56. Leonard, B.M.; Zhou, Q.; Wu, D.; DiSalvo, F.J. Facile Synthesis of PtNi Intermetallic Nanoparticles: Influence of Reducing Agent and Precursors on Electrocatalytic Activity. Chem. Mater. 2011, 23, 1136-1146. [CrossRef]

57. Zou, L.; Fan, J.; Zhou, Y.; Wang, C.; Li, J.; Zou, Z.; Yang, H. Conversion of PtNi alloy from disordered to ordered for enhanced activity and durability in methanol-tolerant oxygen reduction reactions. Nano Res. 2015, 8, 2777-2788. [CrossRef]

58. Chen, L.; Zhu, J.; Wang, J.; Xiao, W.; Lei, W.; Zhao, T.; Huang, T.; Zhu, Y.; Wang, D. Phase conversion of Pt $\mathrm{Ni}_{3} / \mathrm{C}_{\text {from disordered }}$ alloy to ordered intermetallic with strained lattice for oxygen reduction reaction. Electrochim. Acta 2018, 283, 1253-1260. [CrossRef] 
59. Wang, Z.; Yao, X.; Kang, Y.; Miao, L.; Xia, D.; Gan, L. Structurally Ordered Low-Pt Intermetallic Electrocatalysts toward Durably High Oxygen Reduction Reaction Activity. Adv. Funct. Mater. 2019, 29, 1902987. [CrossRef]

60. Gong, M.; Xiao, D.; Deng, Z.; Zhang, R.; Xia, W.; Zhao, T.; Liu, X.; Shen, T.; Hu, Y.; Lu, Y.; et al. Structure evolution of PtCu nanoframes from disordered to ordered for the oxygen reduction reaction. Appl. Catal. B Environ. 2020, 282, 119617. [CrossRef]

61. Oezaslan, M.; Hasché, F.; Strasser, P. In Situ Observation of Bimetallic Alloy Nanoparticle Formation and Growth Using High-Temperature XRD. Chem. Mater. 2011, 23, 2159-2165. [CrossRef]

62. Ortatatlı, Ş; Knossalla, J.; Schuth, F.; Weidenthaler, C. Monitoring the formation of PtNi nanoalloys supported on hollow graphitic spheres using in situ pair distribution function analysis. Phys. Chem. Chem. Phys. 2018, 20, 8466-8474. [CrossRef]

63. Baldizzone, C.; Mezzavilla, S.; Carvalho, H.W.P.; Meier, J.C.; Schuppert, A.K.; Heggen, M.; Galeano, C.; Grunwaldt, J.-D.; Schüth, F.; Mayrhofer, K. Confined-Space Alloying of Nanoparticles for the Synthesis of Efficient PtNi Fuel-Cell Catalysts. Angew. Chem. Int. Ed. 2014, 53, 14250-14254. [CrossRef]

64. Xiong, Y.; Yang, Y.; Joress, H.; Padgett, E.; Gupta, U.; Yarlagadda, V.; Agyeman-Budu, D.N.; Huang, X.; Moylan, T.E.; Zeng, R.; et al. Revealing the atomic ordering of binary intermetallics using in situ heating techniques at multilength scales. Proc. Natl. Acad. Sci. USA 2019, 116, 1974-1983. [CrossRef]

65. Gatalo, M.; Ruiz-Zepeda, F.; Hodnik, N.; Dražić, G.; Bele, M.; Gaberšček, M. Insights into thermal annealing of highly-active $\mathrm{PtCu}$ /C Oxygen Reduction Reaction electrocatalyst: An in-situ heating transmission Electron microscopy study. Nano Energy 2019, 63, 103892. [CrossRef]

66. Gatalo, M.; Bele, M.; Ruiz-Zepeda, F.; Sest, E.; Sala, M.; Kamsek, A.R.; Maselj, N.; Galun, T.; Jovanovic, P.; Hodnik, N.; et al. A Double-Passivation Water-Based Galvanic Displacement Method for Reproducible Gram-Scale Production of High-Performance Platinum-Alloy Electrocatalysts. Angew. Chem. 2019, 58, 13266-13270. [CrossRef] [PubMed]

67. Cui, Z.; Chen, H.; Zhao, M.; Marshall, D.; Yu, Y.; Abruña, H.; Disalvo, F.J. Synthesis of Structurally Ordered Pt3Ti and Pt3V Nanoparticles as Methanol Oxidation Catalysts. J. Am. Chem. Soc. 2014, 136, 10206-10209. [CrossRef] [PubMed]

68. Chen, H.; Wang, D.; Yu, Y.; Newton, K.; Muller, D.; Abruña, H.; Disalvo, F.J. A Surfactant-Free Strategy for Synthesizing and Processing Intermetallic Platinum-Based Nanoparticle Catalysts. J. Am. Chem. Soc. 2012, 134, 18453-18459. [CrossRef]

69. Chen, H.; Yu, Y.; Xin, H.; Newton, K.; Holtz, M.E.; Wang, D.; Muller, D.; Abruña, H.D.; Disalvo, F.J. Coalescence in the Thermal Annealing of Nanoparticles: An in Situ STEM Study of the Growth Mechanisms of Ordered Pt-Fe Nanoparticles in a KCl Matrix. Chem. Mater. 2013, 25, 1436-1442. [CrossRef]

70. Lokanathan, M.; Patil, I.M.; Navaneethan, M.; Parey, V.; Thapa, R.; Kakade, B. Designing of stable and highly efficient ordered Pt2CoNi ternary alloy electrocatalyst: The origin of dioxygen reduction activity. Nano Energy 2018, 43, 219-227. [CrossRef]

71. Elkins, K.; Li, D.; Poudyal, N.; Nandwana, V.; Jin, Z.; Chen, K.; Liu, J.P. Monodisperse face-centred tetragonal FePt nanoparticles with giant coercivity. J. Phys. D Appl. Phys. 2005, 38, 2306-2309. [CrossRef]

72. Cui, Z.; Chen, H.; Zhou, W.; Zhao, M.; Disalvo, F.J. Structurally Ordered Pt3Cr as Oxygen Reduction Electrocatalyst: Ordering Control and Origin of Enhanced Stability. Chem. Mater. 2015, 27, 7538-7545. [CrossRef]

73. Chung, D.Y.; Jun, S.; Yoon, G.; Kwon, S.G.; Shin, D.Y.; Seo, P.; Yoo, J.M.; Shin, H.; Chung, Y.-H.; Kim, H.; et al. Highly Durable and Active PtFe Nanocatalyst for Electrochemical Oxygen Reduction Reaction. J. Am. Chem. Soc. 2015, 137, 15478-15485. [CrossRef]

74. Lee, H.; Dellatore, S.M.; Miller, W.; Messersmith, P. Mussel-Inspired Surface Chemistry for Multifunctional Coatings. Science 2007, 318, 426-430. [CrossRef]

75. Li, J.; Xi, Z.; Pan, Y.-T.; Spendelow, J.S.; Duchesne, P.N.; Su, D.; Li, Q.; Yu, C.; Yin, Z.; Shen, B.; et al. Fe Stabilization by Intermetallic L10-FePt and Pt Catalysis Enhancement in L10-FePt/Pt Nanoparticles for Efficient Oxygen Reduction Reaction in Fuel Cells. J. Am. Chem. Soc. 2018, 140, 2926-2932. [CrossRef]

76. Du, X.X.; He, Y.; Wang, X.X.; Wang, J.N. Fine-grained and fully ordered intermetallic PtFe catalysts with largely enhanced catalytic activity and durability. Energy Environ. Sci. 2016, 9, 2623-2632. [CrossRef]

77. Zhang, S.; Guo, S.; Zhu, H.; Su, D.; Sun, S. Structure-Induced Enhancement in Electrooxidation of Trimetallic FePtAu Nanoparticles. J. Am. Chem. Soc. 2012, 134, 5060-5063. [CrossRef] [PubMed]

78. Li, Q.; Wu, L.; Wu, G.; Su, D.; Lv, H.; Zhang, S.; Zhu, W.; Casimir, A.; Zhu, H.; Mendoza-Garcia, A.; et al. New approach to fully ordered fct-FePt nanoparticles for much enhanced electrocatalysis in acid. Nano Lett. 2015, 15, 2468-2473. [CrossRef]

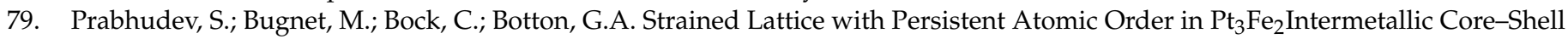
Nanocatalysts. ACS Nano 2013, 7, 6103-6110. [CrossRef]

80. Dutta, I.; Carpenter, M.K.; Balogh, M.P.; Ziegelbauer, J.; Moylan, T.E.; Atwan, M.H.; Irish, N.P. Electrochemical and Structural Study of a Chemically Dealloyed PtCu Oxygen Reduction Catalyst. J. Phys. Chem. C 2010, 114, 16309-16320. [CrossRef]

81. Cui, Z.; Chen, H.; Zhao, M.; Disalvo, F.J. High-Performance $\mathrm{Pd}_{3} \mathrm{~Pb}$ Intermetallic Catalyst for Electrochemical Oxygen Reduction. Nano Lett. 2016, 16, 2560-2566. [CrossRef]

82. Yoo, T.Y.; Yoo, J.M.; Sinha, A.K.; Bootharaju, M.S.; Jung, E.; Lee, H.S.; Lee, B.-H.; Kim, J.; Antink, W.H.; Kim, Y.M.; et al. Direct Synthesis of Intermetallic Platinum-Alloy Nanoparticles Highly Loaded on Carbon Supports for Efficient Electrocatalysis. J. Am. Chem. Soc. 2020, 142, 14190-14200. [CrossRef]

83. Xia, B.Y.; Wu, H.; Wang, X.; Lou, X.W. One-Pot Synthesis of Cubic PtCu3 Nanocages with Enhanced Electrocatalytic Activity for the Methanol Oxidation Reaction. J. Am. Chem. Soc. 2012, 134, 13934-13937. [CrossRef] [PubMed]

84. Varanda, L.C.; Jafelicci, M. Self-Assembled FePt Nanocrystals with Large Coercivity: Reduction of the fcc-to-L10Ordering Temperature. J. Am. Chem. Soc. 2006, 128, 11062-11066. [CrossRef] [PubMed] 
85. Hammer, B.; Norskov, J.K. Why gold is the noblest of all the metals. Nature 1995, 376, 238-240. [CrossRef]

86. Nørskov, J.K.; Studt, F.; Abild-Pedersen, F.; Bligaard, T. Fundamental Concepts in Heterogeneous Catalysis; John Wiley \& Sons: Hoboken, NJ, USA, 2014.

87. Hammer, B.; Nørskov, J. Theoretical surface science and catalysis-Calculations and concepts. Adv. Catal. 2000, 45, 71-129. [CrossRef]

88. Strasser, P.; Koh, S.; Anniyev, T.; Greeley, J.P.; More, K.; Yu, C.; Liu, Z.; Kaya, S.; Nordlund, D.; Ogasawara, H.; et al. Lattice-strain control of the activity in dealloyed core-shell fuel cell catalysts. Nat. Chem. 2010, 2, 454-460. [CrossRef] [PubMed]

89. Luo, M.; Guo, S. Strain-controlled electrocatalysis on multimetallic nanomaterials. Nat. Rev. Mater. 2017, 2, 17059. [CrossRef]

90. Bligaard, T.; Nørskov, J. Ligand effects in heterogeneous catalysis and electrochemistry. Electrochim. Acta 2007, 52, 5512-5516. [CrossRef]

91. Stamenkovic, V.; Mun, B.S.; Mayrhofer, K.J.J.; Ross, P.N.; Markovic, N.M.; Rossmeisl, J.; Greeley, J.; Nørskov, J.K. Changing the Activity of Electrocatalysts for Oxygen Reduction by Tuning the Surface Electronic Structure. Angew. Chem. Int. Ed. 2006, 45, 2897. [CrossRef]

92. Stephens, I.; Bondarenko, A.S.; Perez-Alonso, F.J.; Calle-Vallejo, F.; Bech, L.; Johansson, T.P.; Jepsen, A.K.; Frydendal, R.; Knudsen, B.P.; Rossmeisl, J.; et al. Tuning the Activity of Pt(111) for Oxygen Electroreduction by Subsurface Alloying. J. Am. Chem. Soc. 2011, 133, 5485-5491. [CrossRef]

93. Viswanathan, V.; Hansen, H.A.; Rossmeisl, J.; Nørskov, J.K. Universality in Oxygen Reduction Electrocatalysis on Metal Surfaces. ACS Catal. 2012, 2, 1654-1660. [CrossRef]

94. Nørskov, J.K.; Rossmeisl, J.; Logadottir, A.; Lindqvist, L.; Kitchin, J.; Bligaard, T.; Jónsson, H. Origin of the Overpotential for Oxygen Reduction at a Fuel-Cell Cathode. J. Phys. Chem. B 2004, 108, 17886-17892. [CrossRef]

95. Greeley, J.; Stephens, I.E.L.; Bondarenko, A.S.; Johansson, T.P.; Hansen, H.A.; Jaramillo, T.F.; Rossmeisl, J.; Chorkendorff, I.; Nørskov, J.K. Alloys of platinum and early transition metals as oxygen reduction electrocatalysts. Nat. Chem. 2009, 1, 552. [CrossRef] [PubMed]

96. Stamenkovic, V.R.; Fowler, B.; Mun, B.S.; Wang, G.; Ross, P.N.; Lucas, C.A.; Marković, N.M. Improved Oxygen Reduction Activity on Pt3Ni(111) via Increased Surface Site Availability. Science 2007, 315, 493-497. [CrossRef] [PubMed]

97. Gong, M.; Zhu, J.; Liu, M.; Liu, P.; Deng, Z.; Shen, T.; Zhao, T.; Lin, R.; Lu, Y.; Yang, S.; et al. Optimizing PtFe intermetallics for oxygen reduction reaction: From DFT screening to in situ XAFS characterization. Nanoscale 2019, 11, 20301-20306. [CrossRef]

98. Jia, Q.; Caldwell, K.; Ramaker, D.E.; Ziegelbauer, J.M.; Liu, Z.; Yu, Z.; Trahan, M.; Mukerjee, S. In Situ Spectroscopic Evidence for Ordered Core-Ultrathin Shell Pt1Co1 Nanoparticles with Enhanced Activity and Stability as Oxygen Reduction Electrocatalysts. J. Phys. Chem. C 2014, 118, 20496-20503. [CrossRef]

99. Hodnik, N.; Bele, M.; Rečnik, A.; Logar, N.Z.; Gaberšček, M.; Hočevar, S. Enhanced Oxygen Reduction and Methanol Oxidation Reaction Activities of Partially Ordered PtCu Nanoparticles. Energy Procedia 2012, 29, 208-215. [CrossRef]

100. Lu, F.; Wang, J.; Li, J.; Du, Y.; Kong, X.-P.; Liu, S.; Yi, D.; Takahashi, Y.K.; Hono, K.; Wang, X.; et al. Regulation of oxygen reduction reaction by the magnetic effect of L10-PtFe alloy. Appl. Catal. B Environ. 2020, 278, 119332. [CrossRef]

101. Liu, M.; Xin, H.; Wu, Q. Unusual strain effect of a Pt-based L10 face-centered tetragonal core in core/shell nanoparticles for the oxygen reduction reaction. Phys. Chem. Chem. Phys. 2019, 21, 6477-6484. [CrossRef]

102. Zhao, Z.; Chen, C.; Liu, Z.; Huang, J.; Wu, M.; Liu, H.; Li, Y.; Huang, Y. Pt-Based Nanocrystal for Electrocatalytic Oxygen Reduction. Adv. Mater. 2018, 31, e1808115. [CrossRef]

103. Ma, Z.; Cano, Z.P.; Yu, A.; Chen, Z.; Jiang, G.; Fu, X.; Yang, L.; Wu, T.; Bai, Z.; Lu, J. Enhancing Oxygen Reduction Activity of Pt-based Electrocatalysts: From Theoretical Mechanisms to Practical Methods. Angew. Chem. Int. Ed. 2020, 59, 18334-18348. [CrossRef] [PubMed]

104. Huang, L.; Zaman, S.; Tian, X.; Wang, Z.; Fang, W.; Xia, B.Y. Advanced Platinum-Based Oxygen Reduction Electrocatalysts for Fuel Cells. Acc. Chem. Res. 2021, 54, 311-322. [CrossRef]

105. Zhang, B.; Yang, H.; Wang, Y.; Dou, S.X.; Liu, H. A Comprehensive Review on Controlling Surface Composition of Pt-Based Bimetallic Electrocatalysts. Adv. Energy Mater. 2018, 8, 1703597. [CrossRef]

106. Liu, M.; Zhao, Z.; Duan, X.; Huang, Y. Nanoscale Structure Design for High-Performance Pt-Based ORR Catalysts. Adv. Mater. 2019, 31, e1802234. [CrossRef]

107. Shao, Y.; Yin, G.; Gao, Y. Understanding and approaches for the durability issues of Pt-based catalysts for PEM fuel cell. J. Power Sources 2007, 171, 558-566. [CrossRef]

108. Ferreira, P.J.; Shao-Horn, Y.; Morgan, D.; Makharia, R.; Kocha, S.; Gasteiger, H.A. Instability of Pt/C electrocatalysts in proton exchange membrane fuel cells-A mechanistic investigation. J. Electrochem. Soc. 2005, 152, A2256-A2271. [CrossRef]

109. Chung, D.Y.; Yoo, J.M.; Sung, Y.E. Highly Durable and Active Pt-Based Nanoscale Design for Fuel-Cell Oxygen-Reduction Electrocatalysts. Adv. Mater. 2018, 30, 1704123. [CrossRef]

110. Zhang, J.; Yuan, Y.; Gao, L.; Zeng, G.; Li, M.; Huang, H. Stabilizing Pt-Based Electrocatalysts for Oxygen Reduction Reaction: Fundamental Understanding and Design Strategies. Adv. Mater. 2021, 33, 2006494. [CrossRef] [PubMed]

111. Jinnouchi, R.; Toyoda, E.; Hatanaka, T.; Morimoto, Y. First Principles Calculations on Site-Dependent Dissolution Potentials of Supported and Unsupported Pt Particles. J. Phys. Chem. C 2010, 114, 17557-17568. [CrossRef] 
112. Li, D.; Wang, C.; Strmcnik, D.S.; Tripkovic, D.V.; Sun, X.; Kang, Y.; Chi, M.; Snyder, J.D.; van der Vliet, D.; Tsai, Y.; et al. Functional links between Pt single crystal morphology and nanoparticles with different size and shape: The oxygen reduction reaction case. Energy Environ. Sci. 2014, 7, 4061-4069. [CrossRef]

113. Cao, L.; Zhao, Z.; Liu, Z.; Gao, W.; Dai, S.; Gha, J.; Xue, W.; Sun, H.; Duan, X.; Pan, X.; et al. Differential Surface Elemental Distribution Leads to Significantly Enhanced Stability of PtNi-Based ORR Catalysts. Matter 2019, 1, 1567. [CrossRef]

114. Jia, Q.; Zhao, Z.; Cao, L.; Li, J.; Ghoshal, S.; Davies, V.; Stavitski, E.; Attenkofer, K.; Liu, Z.; Li, M.; et al. Roles of Mo Surface Dopants in Enhancing the ORR Performance of Octahedral PtNi Nanoparticles. Nano Lett. 2018, 18, 798-804. [CrossRef]

115. Wang, C.; Chi, M.; Li, D.; Strmcnik, D.; van der Vliet, D.; Wang, G.; Komanicky, V.; Chang, K.-C.; Paulikas, A.P.; Tripkovic, D.; et al. Design and Synthesis of Bimetallic Electrocatalyst with Multilayered Pt-Skin Surfaces. J. Am. Chem. Soc. 2011, 133, 14396-14403. [CrossRef]

116. Wen, Y.-H.; Huang, R. Effect of Chemical Ordering on Thermal Stability of Pt-Co Nanoparticles. J. Phys. Chem. C 2019, 123, 12007-12014. [CrossRef]

117. Jung, C.; Lee, C.; Bang, K.; Lim, J.; Lee, H.; Ryu, H.J.; Cho, E.; Lee, H.M. Synthesis of Chemically Ordered Pt ${ }_{3} F e / C$ Intermetallic Electrocatalysts for Oxygen Reduction Reaction with Enhanced Activity and Durability via a Removable Carbon Coating. ACS Appl. Mater. Interfaces 2017, 9, 31806-31815. [CrossRef]

118. Li, J.; Sharma, S.; Liu, X.; Pan, Y.-T.; Spendelow, J.S.; Chi, M.; Jia, Y.; Zhang, P.; Cullen, D.A.; Xi, Z.; et al. Hard-Magnet L10-CoPt Nanoparticles Advance Fuel Cell Catalysis. Joule 2018, 3, 124-135. [CrossRef]

119. Lopes, P.; Strmcnik, D.; Tripkovic, D.; Connell, J.G.; Stamenkovic, V.R.; Markovic, N.M. Relationships between Atomic Level Surface Structure and Stability/Activity of Platinum Surface Atoms in Aqueous Environments. ACS Catal. 2016, 6, 2536-2544. [CrossRef]

120. Tritsaris, G.; Greeley, J.P.; Rossmeisl, J.; Nørskov, J.K. Atomic-Scale Modeling of Particle Size Effects for the Oxygen Reduction Reaction on Pt. Catal. Lett. 2011, 141, 909-913. [CrossRef]

121. Perez-Alonso, F.J.; McCarthy, D.N.; Nierhoff, A.; Hernandez-Fernandez, P.; Strebel, C.; Stephens, I.; Nielsen, J.H.; Chorkendorff, I. The Effect of Size on the Oxygen Electroreduction Activity of Mass-Selected Platinum Nanoparticles. Angew. Chem. Int. Ed. 2012, 51, 4641-4643. [CrossRef] [PubMed]

122. Shao, M.; Peles, A.; Shoemaker, K. Electrocatalysis on platinum nanoparticles: Particle size effect on oxygen reduction reaction activity. Nano Lett. 2011, 11, 3714. [CrossRef] [PubMed]

123. Sandbeck, D.J.S.; Secher, N.M.; Speck, F.D.; Sørensen, J.E.; Kibsgaard, J.; Chorkendorff, I.; Cherevko, S. Particle Size Effect on Platinum Dissolution: Considerations for Accelerated Stability Testing of Fuel Cell Catalysts. ACS Catal. 2020, 10, 6281-6290. [CrossRef]

124. Yano, H.; Watanabe, M.; Iiyama, A.; Uchida, H. Particle-size effect of Pt cathode catalysts on durability in fuel cells. Nano Energy 2016, 29, 323-333. [CrossRef]

125. Hu, Y.; Shen, T.; Zhao, X.; Zhang, J.; Lu, Y.; Shen, J.; Lu, S.; Tu, Z.; Xin, H.; Wang, D. Combining structurally ordered intermetallics with N-doped carbon confinement for efficient and anti-poisoning electrocatalysis. Appl. Catal. B Environ. 2020, $279,119370$. [CrossRef]

126. Zhang, B.; Fu, G.; Li, Y.; Liang, L.; Grundish, N.S.; Tang, Y.; Goodenough, J.B.; Cui, Z. General Strategy for Synthesis of Ordered Pt 3 M Intermetallics with Ultrasmall Particle Size. Angew. Chem. Int. Ed. 2020, 59, 7857-7863. [CrossRef] [PubMed]

127. Ma, Y.; Kuhn, A.N.; Gao, W.; Al-Zoubi, T.; Du, H.; Pan, X.; Yang, H. Strong electrostatic adsorption approach to the synthesis of sub-three nanometer intermetallic platinum-cobalt oxygen reduction catalysts. Nano Energy 2020, 79, 105465. [CrossRef]

128. Wang, T.; Liang, J.; Zhao, Z.; Li, S.; Lu, G.; Xia, Z.; Wang, C.; Luo, J.; Han, J.; Ma, C.; et al. Sub-6 nm Fully Ordered L10-Pt-Ni-Co Nanoparticles Enhance Oxygen Reduction via Co Doping Induced Ferromagnetism Enhancement and Optimized Surface Strain. Adv. Energy Mater. 2019, 9, 1803771. [CrossRef]

129. Liang, J.; Zhao, Z.; Li, N.; Wang, X.; Li, S.; Liu, X.; Wang, T.; Lu, G.; Wang, D.; Hwang, B.; et al. Biaxial Strains Mediated Oxygen Reduction Electrocatalysis on Fenton Reaction Resistant L10-PtZn Fuel Cell Cathode. Adv. Energy Mater. 2020, 10, 2000179. [CrossRef]

130. Adzic, R.R. Platinum Monolayer Electrocatalysts: Tunable Activity, Stability, and Self-Healing Properties. Electrocatalysis 2012, 3, 163-169. [CrossRef]

131. Gan, L.; Cui, C.; Rudi, S.; Strasser, P. Core-Shell and Nanoporous Particle Architectures and Their Effect on the Activity and Stability of Pt ORR Electrocatalysts. Top. Catal. 2013, 57, 236-244. [CrossRef]

132. Long, N.V.; Yang, Y.; Thi, C.M.; Van Minh, N.; Cao, Y.; Nogami, M. The development of mixture, alloy, and core-shell nanocatalysts with nanomaterial supports for energy conversion in low-temperature fuel cells. Nano Energy 2013, 2, 636-676. [CrossRef]

133. Oezaslan, M.; Hasché, F.; Strasser, P. Pt-Based Core-Shell Catalyst Architectures for Oxygen Fuel Cell Electrodes. J. Phys. Chem. Lett. 2013, 4, 3273-3291. [CrossRef]

134. Strasser, P.; Kühl, S. Dealloyed Pt-based core-shell oxygen reduction electrocatalysts. Nano Energy 2016, 29, 166-177. [CrossRef]

135. Wang, L.; Zeng, Z.; Ma, C.; Liu, Y.; Giroux, M.; Chi, M.; Jin, J.; Greeley, J.; Wang, C. Plating Precious Metals on Nonprecious Metal Nanoparticles for Sustainable Electrocatalysts. Nano Lett. 2017, 17, 3391-3395. [CrossRef]

136. Wang, D.; Yu, Y.; Xin, H.; Hovden, R.; Ercius, P.; Mundy, J.A.; Chen, H.; Richard, J.H.; Muller, D.; Disalvo, F.J.; et al. Tuning Oxygen Reduction Reaction Activity via Controllable Dealloying: A Model Study of Ordered $\mathrm{Cu}_{3} \mathrm{Pt} / \mathrm{C}$ Intermetallic Nanocatalysts. Nano Lett. 2012, 12, 5230-5238. [CrossRef] [PubMed] 
137. Wang, D.; Yu, Y.; Zhu, J.; Liu, S.; Muller, D.A.; Abruña, H.D. Morphology and Activity Tuning of Cu3Pt/C Ordered Intermetallic Nanoparticles by Selective Electrochemical Dealloying. Nano Lett. 2015, 15, 1343-1348. [CrossRef] [PubMed]

138. Wang, G.; Huang, B.; Xiao, L.; Ren, Z.; Chen, H.; Wang, D.; Abruña, H.D.; Lu, J.; Zhuang, L. Pt Skin on AuCu Intermetallic Substrate: A Strategy to Maximize Pt Utilization for Fuel Cells. J. Am. Chem. Soc. 2014, 136, 9643-9649. [CrossRef]

139. Chen, H.; Zheng, T.; He, Q.; Shang, L.; Wang, G.; Wang, Q.; Wang, X.; Shi, X.; Gu, M.; Jiang, Z. Local Coordination and Ordering Engineering to Design Efficient Core-Shell Oxygen Reduction Catalysts. J. Electrochem. Soc. 2020, 167, 144501. [CrossRef]

140. Zhang, L.; Wilkinson, D.P.; Liu, Y.; Zhang, J. Progress in nanostructured (Fe or Co)/N/C non-noble metal electrocatalysts for fuel cell oxygen reduction reaction. Electrochim. Acta 2018, 262, 326-336. [CrossRef]

141. Xiao, M.; Chen, Y.; Zhu, J.; Zhang, H.; Zhao, X.; Gao, L.; Wang, X.; Zhao, J.; Ge, J.; Jiang, Z.; et al. Climbing the Apex of the ORR Volcano Plot via Binuclear Site Construction: Electronic and Geometric Engineering. J. Am. Chem. Soc. 2019, 141, 17763-17770. [CrossRef]

142. Chung, H.T.; Cullen, D.A.; Higgins, D.; Sneed, B.T.; Holby, E.F.; More, K.L.; Zelenay, P. Direct atomic-level insight into the active sites of a high-performance PGM-free ORR catalyst. Science 2017, 357, 479-484. [CrossRef]

143. Jung, W.S.; Lee, W.H.; Oh, H.-S.; Popov, B.N. Highly stable and ordered intermetallic PtCo alloy catalyst supported on graphitized carbon containing Co@CN for oxygen reduction reaction. J. Mater. Chem. A 2020, 8, 19833-19842. [CrossRef]

144. Shao, Y.; Sui, J.; Yin, G.; Gao, Y. Nitrogen-doped carbon nanostructures and their composites as catalytic materials for proton exchange membrane fuel cell. Appl. Catal. B Environ. 2008, 79, 89-99. [CrossRef]

145. Yu, X.; Ye, S. Recent advances in activity and durability enhancement of Pt/C catalytic cathode in PEMFC: Part II: Degradation mechanism and durability enhancement of carbon supported platinum catalyst. J. Power Sources 2007, 172, 145-154. [CrossRef]

146. Chong, L.; Wen, J.; Kubal, J.; Sen, F.G.; Zou, J.; Greeley, J.; Chan, M.; Barkholtz, H.; Ding, W.; Liu, D.-J. Ultralow-loading platinum-cobalt fuel cell catalysts derived from imidazolate frameworks. Science 2018, 362, 1276-1281. [CrossRef] [PubMed]

147. Ao, X.; Zhang, W.; Zhao, B.; Ding, Y.; Nam, G.; Soule, L.; Abdelhafiz, A.; Wang, C.; Liu, M. Atomically dispersed Fe-N-C decorated with Pt-alloy core-shell nanoparticles for improved activity and durability towards oxygen reduction. Energy Environ. Sci. 2020, 13, 3032-3040. [CrossRef]

148. Wang, X.X.; Hwang, S.; Pan, Y.-T.; Chen, K.; He, Y.; Karakalos, S.G.; Zhang, H.; Spendelow, J.S.; Su, D.; Wu, G. Ordered Pt3Co Intermetallic Nanoparticles Derived from Metal-Organic Frameworks for Oxygen Reduction. Nano Lett. 2018, 18, $4163-4171$. [CrossRef] [PubMed]

149. Zhao, X.; Xi, C.; Zhang, R.; Song, L.; Wang, C.; Spendelow, J.S.; Frenkel, A.I.; Yang, J.; Xin, H.L.; Sasaki, K. High-Performance Nitrogen-Doped Intermetallic PtNi Catalyst for the Oxygen Reduction Reaction. ACS Catal. 2020, 10, 10637-10645. [CrossRef]

150. Zhao, X.; Cheng, H.; Song, L.; Han, L.; Zhang, R.; Kwon, G.; Ma, L.; Ehrlich, S.N.; Frenkel, A.I.; Yang, J.; et al. Rhombohedral Ordered Intermetallic Nanocatalyst Boosts the Oxygen Reduction Reaction. ACS Catal. 2020, 11, 184-192. [CrossRef]

151. Liu, M.; Hu, A.; Ma, Y.; Wang, G.; Zou, L.; Chen, X.; Yang, H. Nitrogen-doped Pt3Co intermetallic compound nanoparticles: A durable oxygen reduction electrocatalyst. J. Electroanal. Chem. 2020, 871, 114267. [CrossRef]

152. Kim, H.Y.; Kwon, T.; Ha, Y.; Jun, M.; Baik, H.; Jeong, H.Y.; Kim, H.; Lee, K.; Joo, S.H. Intermetallic PtCu Nanoframes as Efficient Oxygen Reduction Electrocatalysts. Nano Lett. 2020, 20, 7413-7421. [CrossRef]

153. Zhang, S.; Zhang, X.; Jiang, G.; Zhu, H.; Guo, S.; Su, D.; Lu, G.; Sun, S. Tuning Nanoparticle Structure and Surface Strain for Catalysis Optimization. J. Am. Chem. Soc. 2014, 136, 7734-7739. [CrossRef]

154. Li, J.; Sharma, S.; Wei, K.; Chen, Z.; Morris, D.; Lin, H.; Zeng, C.; Chi, M.; Yin, Z.; Muzzio, M.; et al. Anisotropic Strain Tuning of L10 Ternary Nanoparticles for Oxygen Reduction. J. Am. Chem. Soc. 2020, 142, 19209-19216. [CrossRef] [PubMed]

155. Gao, P.; Cai, Y.; Wang, F.; Zhu, H.; Pu, M. Pt-based trimetallic nanocrystals with high proportions of M (M=Fe, Ni) metals for catalyzing oxygen reduction reaction. Int. J. Hydrogen Energy 2020, 45, 16039-16048. [CrossRef]

156. Wang, X.; Zhang, L.; Wang, F.; Yu, J.; Zhu, H. Nickel-introduced structurally ordered PtCuNi/C as high performance electrocatalyst for oxygen reduction reaction. Prog. Nat. Sci. 2020, 30, 905-911. [CrossRef]

157. Zhang, L.; Ji, X.; Wang, X.; Fu, Y.; Zhu, H.; Liu, T. Chemically Ordered Pt-Co-Cu/C as Excellent Electrochemical Catalyst for Oxygen Reduction Reaction. J. Electrochem. Soc. 2020, 167, 024507. [CrossRef]

158. Wang, Z.; Yao, X.; Kang, Y.; Xia, D.; Gan, L.; Wang, Y.; Kang, X. Gan Rational Development of Structurally Ordered Platinum Ternary Intermetallic Electrocatalysts for Oxygen Reduction Reaction. Catalysts 2019, 9, 569. [CrossRef]

159. Liang, J.; Li, N.; Zhao, Z.; Ma, L.; Wang, X.; Li, S.; Liu, X.; Wang, T.; Du, Y.; Lu, G.; et al. Tungsten-Doped L10 -PtCo Ultrasmall Nanoparticles as a High-Performance Fuel Cell Cathode. Angew. Chem. 2019, 58, 15471-15477. [CrossRef] [PubMed]

160. Li, J.; Jilani, S.; Lin, H.; Liu, X.; Wei, K.; Jia, Y.; Zhang, P.; Chi, M.; Tong, Y.J.; Xi, Z.; et al. Ternary CoPtAu Nanoparticles as a General Catalyst for Highly Efficient Electro-oxidation of Liquid Fuels. Angew. Chem. Int. Ed. 2019, 58, 11527-11533. [CrossRef] [PubMed]

161. Choi, J.; Cho, J.; Roh, C.-W.; Kim, B.-S.; Choi, M.S.; Jeong, H.; Ham, H.C.; Lee, H. Au-doped PtCo/C catalyst preventing Co leaching for proton exchange membrane fuel cells. Appl. Catal. B Environ. 2019, 247, 142-149. [CrossRef]

162. Lopes, P.P.; Li, D.; Lv, H.; Wang, C.; Tripkovic, D.; Zhu, Y.; Schimmenti, R.; Daimon, H.; Kang, Y.; Snyder, J.; et al. Eliminating dissolution of platinum-based electrocatalysts at the atomic scale. Nat. Mater. 2020, 19, 1207-1214. [CrossRef]

163. Gatalo, M.; Jovanovič, P.; Polymeros, G.; Grote, J.-P.; Pavlišič, A.; Zepeda, F.R.; Šelih, V.S.; Šala, M.; Hočevar, S.; Bele, M.; et al Positive Effect of Surface Doping with Au on the Stability of Pt-Based Electrocatalysts. ACS Catal. 2016, 6, 1630-1634. [CrossRef] 
164. Wang, H.; An, W. Promoting the oxygen reduction reaction with gold at step/edge sites of Ni@AuPt core-shell nanoparticles. Catal. Sci. Technol. 2017, 7, 596-606. [CrossRef]

165. He, Y.; Wu, Y.L.; Zhu, X.X.; Wang, J.N. Remarkable Improvement of the Catalytic Performance of PtFe Nanoparticles by Structural Ordering and Doping. ACS Appl. Mater. Interfaces 2019, 11, 11527-11536. [CrossRef]

166. Zhu, H.; Cai, Y.; Wang, F.; Gao, P.; Cao, J. Scalable Preparation of the Chemically Ordered Pt-Fe-Au Nanocatalysts with High Catalytic Reactivity and Stability for Oxygen Reduction Reactions. ACS Appl. Mater. Interfaces 2018, 10, 22156-22166. [CrossRef] [PubMed]

167. Kim, J.; Hong, Y.; Lee, K.; Kim, J.Y. Highly Stable Pt-Based Ternary Systems for Oxygen Reduction Reaction in Acidic Electrolytes. Adv. Energy Mater. 2020, 10, 2002049. [CrossRef]

168. Wang, Q.; Zhao, Z.L.; Zhang, Z.; Feng, T.; Zhong, R.; Xu, H.; Pantelides, S.T.; Gu, M. Sub-3 nm Intermetallic Ordered Pt 3 In Clusters for Oxygen Reduction Reaction. Adv. Sci. 2019, 7, 1901279. [CrossRef] [PubMed]

169. Choi, D.S.; Robertson, A.; Warner, J.H.; Kim, S.O.; Kim, H. Low-Temperature Chemical Vapor Deposition Synthesis of Pt-Co Alloyed Nanoparticles with Enhanced Oxygen Reduction Reaction Catalysis. Adv. Mater. 2016, 28, 7115-7122. [CrossRef] [PubMed]

170. Wang, S.; Xu, W.; Zhu, Y.; Luo, Q.; Zhang, C.; Tang, S.; Du, Y. Synthesis of Structurally Stable and Highly Active PtCo3 Ordered Nanoparticles through an Easily Operated Strategy for Enhanced Oxygen Reduction Reaction. ACS Appl. Mater. Interfaces 2020, 13, 827-835. [CrossRef] [PubMed] 